\title{
HUMAN WORTH AS COLLATERAL
}

\author{
Rashmi Dyal-Chand*
}

\begin{abstract}
Human worth has taken on a surprising new role: that of market asset. Specifically, lenders in radically different contexts are using their borrowers' human worth as collateral in loan transactions. The two examples of this new collateralization that I examine are credit card lending in the United States and microlending programs in the Third World. I conclude that the use of human worth in these two contexts is too similar to be coincidental. Rather, this new collateralization is a product of globalization. For those interested in the effect of law on globalization, this convergence in the market for credit teaches important lessons. In both the contexts I examine, the laws governing secured and unsecured lending fail to recognize human worth as collateral. For this reason, the new collateralization serves as a counter-example to the claimed centrality of the rule of law in economic development.
\end{abstract}

\section{INTRODUCTION}

A powerful convergence is occurring among radically different markets for credit. Lenders with little else in common are using human worth ${ }^{1}$ as collateral in credit transactions. Yet the law has failed to recognize this new collateralization so completely that the idea of human worth as collateral seems quite shocking. This failure suggests that the formal rule of law is a less effective disseminator of utilitarian norms than its proponents believe, while the globalizing market for credit is quite effective. The emergence of this new collateralization thus challenges the primacy of the rule of law at a time when many are touting it as the key to economic development.

This article examines two modern examples of this new collateralization that are at geographical, economic, and cultural extremes. The first occurs in the context of credit card lending to consumers in the United States. The

\footnotetext{
*Associate Professor of Law, Northeastern University School of Law. I am grateful to Judith Olans Brown, Peter Enrich, Benjamin Ericson, Ingrid Michelsen Hillinger, Mary O'Connell and Joseph Singer for their invaluable comments. An earlier version of a portion of this article was presented at the 2004 Conference on The Law of Dignity/The Politics of Shame at Harvard Law School. I am indebted to Alfreda Russell, in the Northeastern University School of Law Library, for her terrific research support, and to Heather Southwell, Louis Rambo, and Matthew Greene for their outstanding research assistance.

${ }^{1}$ I will discuss the more specific and nuanced variants of human worth as collateral in Part III.
} 
second occurs in microlending programs used widely in developing countries as a means of economic development of the poor. The first involves middle class ${ }^{2}$ people in the First World. ${ }^{3}$ The second example involves impoverished women in the Third World. The two socio-cultural settings could not be more distinct. Yet, stated bluntly, in both cases human worth has taken on a new role as a market asset: the subject of quantification, collateralization, and even liquidation.

This article proceeds as follows. Part I briefly reviews collateral in loan transactions to delineate its advantages and key features. As I discuss, its key features are generally the things that make collateral useful to lenders. Part I also discusses the relationship between collateral and the rule of law. I discuss the traditional assumption that legal rules governing secured lending and other areas of commerce are integral to economic development. If this assumption is correct, it should mean that the law accurately reflects (indeed dictates) what can be collateralized and how collateral is used. I begin here to lay the groundwork for my analysis in Part II of human worth as collateral.

Part II, the heart of this article, sets forth the basis for my hypothesis that lenders in very different contexts have begun to collateralize human worth. I build my case on two examples. The first is the puzzlingly high level of unsecured lending to American consumers by means of the credit card, despite the ease of secured home equity lending. I conclude that this mystery is partly explained by credit card lenders' collateralization of human worth through the mechanism of credit reporting. The second example is the puzzlingly high level of unsecured lending to impoverished rural women in Bangladesh by means of the Grameen Bank's microlending program. I conclude that this mystery is also explained by the lender's collateralization of human worth, this time through the mechanism of peer lending.

\footnotetext{
${ }^{2}$ This article uses the term "middle class" to refer to members of US society in the middle and upper economic classes, and to distinguish this group of people from those who cannot easily participate (or participate at all) in the mainstream market for credit, housing and other services.

${ }^{3}$ This article uses the terms "First World" and the "West" interchangeably and "Third World" and the "East" interchangeably because these are the most recognizable terms used, including in the scholarly literature. See, e.g., Hernando De Soto, The Other Path: The Invisible Revolution In THE Third World (1990); PAul W. Kahn, The Cultural Study of Law: Reconstructing Legal Scholarship 4 (1999) ("third world"); Dustin N. Sharp, Prosecutions, Development, and Justice: The Trial of Hissein Habré, 16 HARVARD HuM. RTs. J. 147 (2003) ("third world"); Amy L. Chua, Markets, Democracy, And Ethnicity: Toward A New Paradigm for Law and Development, 108 Yale L. J. 1 (1998) ("West"); Chandra TalPade Mohanty, ET AL., Third World WoMen AND THE POLITICS OF FeMINISM (1991); GAYATRI ChAKRAVORTY SPIVAK, Can the Subaltern Speak?, in MARXISM AND THE INTERPRETATION OF CULTURE 271, 296-97 (Cary Nelson \& Lawrence Grossberg eds., 1988) ("third world"). These terms are less than ideal, however, not least of all because they contribute to overgeneralizations.
} 
In this part, I return to the literature on secured lending explicitly to analyze the market value of human worth as collateral. I conclude that, from an economic perspective, human worth has several characteristics that make it a valuable asset, and that these features allow lenders to use it much as they would use any other type of collateral. However, the law does not recognize human worth as collateral. Nor does it recognize human worth as relevant to unsecured lending decisions, for example as a substitute for collateral. Importantly, my purpose in analyzing human worth as collateral is not to challenge the distinction between secured and unsecured lending. I acknowledge the bright line between these two forms of lending and the possibility that legal recognition of lenders' use of human worth might not result in changes to Article 9 of the Uniform Commercial Code or its Bangladeshi equivalent. ${ }^{4}$ Rather, my purpose is to show that lenders have succeeded in capturing a valuable new asset as leverage, but that the law has been irrelevant to this important new development in lending.

In Part III, I begin the process of understanding what this new form of collateral really is. I do so both to clarify what exactly is at stake and to understand whether the same thing is at stake in both my examples. Using legal and philosophical discussions of personhood, property and dignity, I explore the social construction of human worth as collateral. I conclude that it is not entirely clear what this new collateral is, but that certain cultural images of dignity and personhood seem to fit. These images resonate in both my examples, suggesting that human worth as collateral has at least some features that are surprisingly homogenous, despite extensive socio-cultural differences.

In Part IV, I reflect on what these two examples might teach about my hypothesis. I conclude that globalization has played a central role in producing the convergence among lending practices described here. However, contrary to the expectations of rule of law proponents, it appears to be the credit market, rather than law, that has produced the utilitarian use of human worth as collateral.

\section{Collateral: Its Advantages, FeAtures AND Relationship to the RULE OF LAW}

Collateral is "[p]roperty that is pledged as security against a debt." ${ }^{5}$

\footnotetext{
${ }^{4}$ In discussing the law on secured lending, I focus more on secured transactions law rather than real estate law, because to the extent human worth can be described as property and collateral, it is personal property rather than real property.

${ }^{5}$ BLACK'S LAW DictionaRY (8th ed. 2004). Security is "[c]ollateral given or pledged to guarantee the fulfillment of an obligation; esp[ecially] the assurance that a creditor will be repaid (usu[ually] with interest) any
} 


\section{A. Advantages}

Legal and economic scholarship has largely answered the question why lenders require collateral. ${ }^{6}$ The most obvious reason is that collateral serves as a means of collecting payment by foreclosure or repossession. ${ }^{7}$ But neither foreclosure nor repossession presents an easy path to repayment, ${ }^{8}$ and it is questionable whether lenders would engage in as much secured lending as they do if this was the only advantage of collateral. ${ }^{9}$ Empirical research suggests that collateral also benefits lenders by motivating borrowers to behave prudently. ${ }^{10}$ The fear of losing an important asset prevents borrowers from taking risks that they otherwise might have taken. $^{11}$ A related benefit is that collateral motivates the borrower to repay the loan voluntarily. ${ }^{12}$ Collateral also saves lenders the costs of monitoring the borrower's behavior. ${ }^{13}$ By taking a security interest in a specific asset, the lender needs only to monitor the borrower's use of that asset, primarily to ensure that the borrower does not pledge it to anyone else, sell it, or otherwise compromise the lender's interest in it. ${ }^{14}$ Whether because of the rise in intellectual property as collateral or otherwise, contemporary secured lending seems to emphasize these additional benefits while relying less on the original purpose of collateral as a means of payment collection. ${ }^{15}$

money or credit extended to a debtor." Id. Unless otherwise specified, I will use the terms security and collateral interchangeably in this article.

${ }^{6}$ The reason seems the same when the collateral is real or personal. Ronald J. Mann, Explaining the Pattern of Secured Credit, 110 HARv. L. Rev. 625, 639 (1996-97) [hereinafter Mann, Explaining the Pattern]. See generally LYNN M. LOPUCKI \& ElIZABETH WARREN, SECURED CREDIT: A SYSTEMS APPROACH (1995).

${ }^{7}$ William D. Warren \& Steven D. Walt, Secured Transactions in Personal Property 2 (2004); Mann, Explaining the Pattern, supra note 6, at 639; Lynn M. LoPucki, The Unsecured Creditor's Bargain, 80 VA. L. REv. 1887, 1921-23 (1994); David Gray Carlson, On the Efficiency of Secured Lending, 80 VA. L. REV. 2179, 2188-89 (1994).

${ }^{8}$ Even in states allowing non-judicial foreclosure, it is a relatively time-consuming and rigorous process, regulating such things as notice and rights of redemption. GRANT S. NELSON \& DALE A. WhitMAN, REAL Estate Finance Law 582-583 (4th ed. 2001); George E. Osborne, Mortgages, 732-736 (2d. ed. 1970). Similarly, notice requirements and prohibitions on breaching the peace typically limit even self-help repossessions. CAROlyn L. Carter et al., National Consumer law Center, Repossessions and FORECLOSURES, Chapter $6\left(5^{\text {th }}\right.$ ed. 2002).

${ }^{9}$ There is a growing literature that argues that the benefit of foreclosure or repossession is not necessarily what drives lenders to take security interests. See, e.g., Ronald J. Mann, Secured Credit And Software Financing, 85 Corn L. Rev. 134, 138-154 (1999) [hereinafter Software Financing]; Mann, Explaining the Pattern, supra note 6, at 639-640; Robert E. Scott, A Relational Theory of Secured Financing, 86 CoLUM. L. REv. 901, 950 (1986). My hypothesis that lenders are using human worth as collateral lends some support to this position.

${ }_{10}^{10}$ Mann, Explaining the Pattern, supra note 6, at 641. For non-empirical support for this argument, see Carlson, supra note 7, at 2186-89,

${ }^{11}$ Indeed, Carlson argues that fear is the primary benefit of secured lending. Carlson, supra note 7, at 2188.

${ }^{12}$ Elizabeth Warren \& Jay LaWrence Westbrook, The Law of Debtors and Creditors: Text, CASES, AND Problems 4-5 (5 $5^{\text {th }}$ ed., 2006); Mann, Explaining the Pattern, supra note 6, at 646.

${ }^{13}$ Mann, Explaining the Pattern, supra note 6, at 650-651; Carlson, supra note 7, at 2189-90; Scott, supra note 9 , at 909-910.

${ }^{14}$ Saul Levmore, Monitors and Freeriders in Commercial and Corporate Settings, 92 YALE L. J. 49, 51-52 (1982).

${ }_{15}$ See Mann, Software Financing, supra note 9, at 136. This is not to say that these additional benefits themselves are new, but rather that they seem to have even more primacy in contemporary transactions. 
The aggregate effect of these advantages to the lender is that the lender is able to provide credit at lower costs than it otherwise would. ${ }^{16}$ Conventional thinking is that this is also the primary benefit to borrowers because it allows borrowers who might otherwise not qualify for a loan to do so, thereby improving their economic condition. ${ }^{17}$

\section{B. Features}

From these advantages, it is possible to develop a list of features that are fundamental to the definition of collateral. First, the lender will not have a specific enough basis for underwriting its loan unless the collateral is fixed in the sense of being quantifiable by the lender. This feature also, of course, allows the collateral to serve as a means of collecting payment. ${ }^{18}$ This does not necessarily mean that collateral must be physical; intellectual property ${ }^{19}$ payment intangibles, ${ }^{20}$ and good will ${ }^{21}$ are all regularly used as collateral for business loans. In the consumer context, stocks and bonds can serve as collateral. Second, collateral generally must be capable of liquidation, because the lender must have a means of taking something meaningful away from the borrower. Consider a piece of intellectual property, such as a process for turning lead into gold. If the borrower secures a loan using this process as collateral and then defaults on the loan, the lender must have a way to prevent the borrower from continuing to use the process for free or to license it to others. Otherwise, the borrower will have no incentive to repay the loan. ${ }^{22}$ The possibility of liquidation is also important because most lenders would prefer to sell the asset for cash rather than acquire the asset as a means of economic production.

A third feature that enhances an asset's value as collateral is its ability to appreciate in value. Real estate serves as a useful example here too. When

\footnotetext{
${ }^{16}$ Carlson, supra note 7, at 2190-91.

${ }^{17}$ Carlson, supra note 7, at 2190-95. Thus, collateral helps to avoid the problem of credit rationing. See Keith N. Hylton, Banks And Inner Cities: Market And Regulatory Obstacles To Development Lending, 17 YALE J. ON REG. 197, 212-217 (2000). See generally Joseph E. Stiglitz \& Andrew Weiss, Credit Rationing in Markets with Imperfect Information, 71 AM. ECON. REV. 393 (1981).

${ }^{18}$ See, e.g., Roy N. Freed, Security Interests in the Computer Age: Practical Advice for the Secured Lender, 101 BANKING L. J. 404 (1984) (both needs are discussed in the context of intellectual property as collateral).

${ }^{19}$ Id. See also U.C.C. § 9-102 cmt. 5(d) (2005) ("General intangible" is the residual category of personal property, including things in action, that is not included in the other defined types of collateral. Examples are various categories of intellectual property and the right to payment of a loan of funds that is not evidenced by chattel paper or an instrument.").

${ }^{20}$ U.C.C. § 9-102(61) (2005) ("'Payment intangible" means a general intangible under which the account debtor's principal obligation is a monetary obligation.")

${ }^{21}$ See, e.g., Bank of Washington v. Burgraff, 687 P.2d 236, 240 (Wash. App. 1984).

${ }^{22}$ See generally Freed, supra note 18 (discussing the ways in which to secure intellectual property so that it can be efficiently foreclosed upon). Professor Mann strongly refutes the importance of this feature in his empirical study of software financing. See generally Mann, Software Financing, supra note 9.
} 
a piece of property appreciates, the lender has more of a cushion to cover its loan, more leverage with which to constrain the borrower's behavior, ${ }^{23}$ and more opportunity to be creative in finding remedies that protect its own interests while not being as onerous for the borrower. ${ }^{24}$

Fourth, to increase the likelihood both that the borrower will behave prudently and that she will repay the loan voluntarily, the collateral must be meaningful to the borrower. Obviously, if a borrower collateralizes a trade secret that is not central to her business (or, in the consumer context, a watch that he finds ugly rather than his wedding ring $^{25}$ ), she will not be as motivated to behave as carefully as if she had collateralized a secret that was central to her business. Fifth, collateral that is easy, and thus not costly, to monitor is also more attractive to lenders. ${ }^{26}$

A sixth feature of collateral is that it can be repossessed or transferred. Although this feature was essential to fulfilling collateral's original purpose of payment collection, it appears less essential in contemporary lending practices. As Ronald Mann's discussion of software as collateral shows, this feature is largely irrelevant to the thriving industry of secured lending to software firms. ${ }^{27}$ Indeed, Professor Mann's work equally implicates the importance of ease of liquidation as a feature of collateral. ${ }^{28}$

These features are neither exhaustive nor mandatory in defining collateral. Nor are they ubiquitously identified in the literature as the defining features of collateral. I suspect this is true in part because they are so obvious. Indeed, I have developed them through a deductive process of analyzing the advantages of collateral that are well-recognized in scholarship. Nonetheless, secured transactions law does implicitly recognize these features. Uniform Commercial Code Section 9-108, for example, requires more than a "supergeneric" identification of the property, presumably so that it can be quantified by the creditor. ${ }^{29}$ Moreover, the

${ }^{23}$ Shared appreciation mortgages exemplify these advantages, allowing the lender to share in the appreciation of the mortgaged property as more of an "owner." For discussions of shared appreciation mortgages, see Ronald Friend, Shared Appreciation Mortgages, 34 Hastings L. J. 329 (1982); Helen Jean Walleser, Balancing the Interest: The Changing Complexion of Home Mortgage Financing in America, 31 DRAKE L. REV. $1(1981-82)$

${ }^{24}$ Gerald Korngold \& Paul Goldstein, ReAl Estate Transactions 807 ( $4^{\text {th }}$ ed. 2002).

${ }^{25}$ I adopt here Margaret Jane Radin's example of the wedding ring as a personal object that is typically very important to the wearer. Margaret Jane Radin, Property and Personhood, 34 STAN. L. REV. 957, 959-961 (1982) [hereinafter, Property and Personhood].

${ }^{26}$ For discussions of the benefits of security in lowering the costs of lenders' monitoring activities, see Mann, Explaining the Pattern, supra note 6, at 650-651; Levmore, supra note 14; Carlson, supra note 7, at 218990 .

${ }^{27}$ See generally Mann, Software Financing, supra note 9.

${ }^{28} I d$.

${ }^{29}$ U.C.C. $\$ 9-108$ (c) (2005). The description requirement in consumer transactions is even more stringent. See U.C.C. § 9-108(e) (2005). As described in the official comment to this section, § 9-108(e) "requires greater 
infrastructure of Article 9 obviously serves the purpose of allowing priority in liquidation of assets. ${ }^{30}$

\section{Collateral and the Rule of Law}

The rule of law is a cornerstone of Western law and policy. As Brian Tamanaha recently stated in his comprehensive discussion of its history, the "apparent unanimity in support of the rule of law is a feat unparalleled in history. No other single political ideal has ever achieved global endorsement." 31 Although the definition of the rule of law is more contested than its importance, a relatively standard description is that the rule of law requires clear, transparent and generally applicable legal rules that are stable over time, and further that there must be "consistency between the rules and the actual conduct of legal actors." ${ }^{, 32}$ It is also orthodoxy, at least among Western development specialists, that the rule of law is critical to economic development, ${ }^{33}$ at least in part because it reduces costs by allowing market participants to predict the legal effects of their actions. $^{34}$ Indeed, some have described the rule of law as the key factor required to mimic the economic success of Western markets. ${ }^{35}$

Given the importance both of the rule of law and of credit to Western economies, ${ }^{36}$ we should expect to see well-developed secured transactions laws in the West and attempts to transfer them to developing countries. ${ }^{37}$ And we do. In the US, for example, many hours were recently dedicated to

specificity of description in order to prevent debtors from inadvertently encumbering certain property."). U.C.C. $\S 9-108$ cmt. 5 (2005)

${ }^{30}$ U.C.C. $\$ 9-101 \mathrm{cmt} .1$ (2002) (Article 9 "provides a comprehensive scheme for the regulation of security interests in personal property and fixtures."). See also Carlson, supra note 7, at 2190-92;

${ }^{31}$ BRIAN Z. TAMANAHA, ON THE RULE OF LAW: History, POLITICS, THEORY 3 (2004).

${ }^{32} I d$. at 93 , summarizing the definition propounded by Lon Fuller. Additionally, the rule of law means "prohibitions against retroactivity, against contradictions and against requiring the impossible." Id. Professor Tamanaha describes this as the predominant "formal" version of the rule of law, as distinguished from the more substantive versions which include conceptions of individual rights or other "moral" content. Id. at 91-92.

${ }^{33} I d$. at 2.

${ }^{34} \mathrm{Id}$. at 119 . For this reason, both the World Bank and the International Monetary Fund have strongly endorsed the rule of law as a condition of financial assistance. $I d$. at 2.

${ }^{35}$ See generally, HERNANDO DE SOTO, THE MYSTERY OF CAPITAL (2000) (focusing on formalization of property rights). For additional definitions and general discussions of the rule of law, see John K.M. Ohnesorge, The Rule of Law, Economic Development, and the Development States of Northeast Asia, in LAW AND DeVelopment in East and Southeast Asia 91 (Christoph Antons, ed., 2003); Randall PeEREnboom, CHINA'S LONG MARCH TOWARD RULE OF LAW (2002).

${ }^{36}$ I will discuss the enormous importance of credit to US consumers in Part II.A.1.

${ }^{37} \mathrm{I}$ am accepting for these purposes the common view that the West is economically more developed than the East, and further, that this prompts the West to attempt to develop Eastern economies. For discussions of these common assumptions, see Amy L. Chua, Markets, Democracy, and Ethnicity: Toward a New Paradigm for Law and Development, 108 YALE L. J. 1 (1998); David Kennedy, The International Anti-Corruption Campaign, 14 Conn. J. OF INT'L L. 455 (1999); James Thuo Gathii, Retelling Good Governance Narratives on Africa's Economic and Political Predicaments: Continuities and Discontinuities in Legal Outcomes Between Markets and States, 45 VILL. L. REV. 971 (2000). 
revising Article 9. ${ }^{38}$ Secured transactions law is also prominently among the array of laws exported by the US and Western Europe to newly independent and developing countries. ${ }^{39}$ The prominence of secured transactions law rests on at least two assumptions. The first assumption is that lenders will value the predictability, transparency and clarity resulting from legal rules governing the behavior of parties in secured lending transactions. $^{40}$ The second is that secured transactions law accurately reflects, if not dictates, important aspects of the parties' behavior. If this second assumption was not true, then the rule of law obviously would not succeed as well in promoting predictability.

Thus, we should also expect to see secured transactions laws, in both their original US and exported versions, predicting and managing what can be collateralized, the terms of secured lending and the consequences of defaults. As the examples in Part II show, however, the law of secured lending does not appear to play nearly so central a role.

\section{Human Worth IN THE MARKETPLACE FOR CREDIT}

In this section, I discuss a pair of mysteries. The first is the high volume of unsecured consumer lending in the US, most prominently in the form of credit card lending, despite the ease of secured lending (namely home equity lending). The second is the high volume of unsecured loans to, and extraordinarily low default rate of, impoverished borrowers involved in peer lending microcredit programs, most prominently that of the Grameen Bank in Bangladesh. ${ }^{41}$ Using traditional assumptions, the lenders' behavior in each of these circumstances does not appear rational. Given the advantages of security that I have outlined above, in both contexts, the risk of borrower default should cause lenders either to require collateral or not to lend as extensively. Yet in both, lenders do lend extensively without requiring collateral, and the rate of borrower default is surprisingly low. ${ }^{42}$

\footnotetext{
${ }^{38}$ For a discussion of some of the effects of the revisions, see Ingrid Michelsen Hillinger \& Michael G. Hillinger, 2001: A Code Odyssey (New Dawn for the Article 9 Secured Creditor), 106 COMMERCIAL L. J. 105 (2001).

${ }^{39}$ See, e.g., David S. Bernstein, Process Drives Success: Key Lessons From a Decade of Legal Reform, in LAW IN TRANSITION, 2-13 (European Bank for Reconstruction and Development, 2002).

${ }^{40}$ TAMANAHA, supra note 31 , at 119 .

${ }^{41}$ These mysteries present the same basic question: why is there so much unsecured lending? As I discuss, although there is a powerful convergence between cultures causing lenders to lend so extensively on an unsecured basis, there are also many contributing factors that are specific to each society.

${ }^{42}$ Regarding default rates in the US, see, e.g., Remarks by Chairman Alan Greenspan The mortgage market and consumer debt at America's Community Bankers Annual Convention, Washington, D.C. October 19, 2004, available at http://www.federalreserve.gov/BOARDDOCS/Speeches/2004/20041019/default.htm ("In recent years, banks and thrifts have been experiencing low delinquency rates on home mortgage and credit card debt, a situation suggesting that the vast majority of households are managing their debt well."). The questions of whether the default rate of consumer credit card borrowers is high or low, and whether it should be lower, are both quite contested, however. See, e.g., Walter V. Robinson and Beth Healy, Regulators, Policy Makers Seldom
} 
I hypothesize that both mysteries are partly explained by the collateralization of something more ethereal even than good will, namely human worth. As I discuss, human worth as collateral has many of the features of collateral. However, laws governing both secured and unsecured lending have failed to recognize the new leveraging of human worth.

\section{A. Credit Reporting}

"Manuela Cormier is one among the millions. Waiting with 100 other forlorn debtors in a three-hour queue at the New Bedford District court last Nov. 30, Cormier stood convicted of misfortune: Five years ago, the 45year-old single mother lost her job and had no money to make payments on a $\$ 1000$ credit card bill. The combination of a 29 percent interest rate, penalty fees, and court-imposed costs have since pushed the bill close to $\$ 4,000$. Cormier was told she would be jailed if she did not pay."43

Recent scholarship has focused significant attention on the enormous amounts of debt shouldered by American consumers. ${ }^{44}$ Much of this consumer debt is secured (often in the form of home equity loans, which are still on the rise $\left.{ }^{45}\right){ }^{46}$ A vast amount of consumer debt, however, is

Intervene, BOSTON GLOBE, Aug. 2, 2006, http://www.boston.com/news/special/spotlight_debt/part4/page1.html (describing "alarming" date from Experian that approximately 20 million Americans are at least 3 months past due on credit card accounts). Regarding default rates in the Grameen Bank program, see Grameen Bank Homepage, Credit Delivery System, http://www.grameen-info.org/bank/cds.html (stating that the repayment rate of borrowers is currently $95 \%$ ).

${ }^{43}$ Robinson \& Healy, supra note 42.

${ }^{44}$ See, e.g., Teresa A. Sullivan ET Al., The Fragile Middle Class 18 (2000) ("From 1980 to 1994, total household debt had increased from 65 percent to 81 percent of total income. In short, real consumer debt has risen dramatically over a long period during which real incomes for many people have stated the same or declined."). See generally Robert D. ManNing, CRedit CARD Nation (2000); Lloyd Klein, IT'S IN the CARDS: CONSUMER CREdiT AND THE AMERICAN EXPERIENCE (1999); JAMES MEDOFF \& ANDREW HARleSS, The InDEBTED SOCIETY: ANATOMY OF AN ONGOING DisAster (1996); Oren Bar-Gill, Seduction by Plastic, 98 Nw. U. L. Rev. 1373 (2004); Julia Patterson Forrester, Mortgaging the American Dream: A Critical Evaluation of the Federal Government's Promotion of Home Equity Financing, 69 TuL. L. REV. 373, 377 (1994).

45 Remarks by Chairman Alan Greenspan The mortgage market and consumer debt, at America's Community Bankers Annual Convention, Washington, D.C. October 19, 2004 http://www.federalreserve.gov/BOARDDOCS/Speeches/2004/20041019/default.htm (home equity loans were still on the rise as of Greenspan's 2004 speech); David Myron, Home Equity Debt Soars, AMERICAN DEMOGRAPHICS (Nov 1, 2004), available at http://www.findarticles.com/p/articles/mi_m4021/is_9_26/ai_n6344044 (relying on statistics maintained by the Federal Deposit Insurance Corporation, available at http://www.fdic.gov/bank/analytical/regional/ro20044q/na/2004winter_03.html).

${ }^{46}$ According to 2003 Census figures, approximately 65 percent of homeowners had mortgages of some sort on their homes. U.S. Census Bureau, American Housing Survey for the United States: 2003, http://www.census.gov/hhes/www/housing/ahs/ahs03/tab315.htm. Moreover, Professors Sullivan, Warren and Westbrook state, on the basis of 1991 census figures, that "[m]ore than 90 percent of homebuyers need a mortgage to purchase a home." SULlivan ET AL., supra note 44, at 206. 2003 census data show that more than 15 percent of all housing owned in the US is encumbered by home equity lump-sum mortgages and/or lines of credit. U.S. Census Bureau, American Housing Survey for the United States: 2003, http://www.census.gov/hhes/www/housing/ahs/ahs03/tab315.htm. 
unsecured. Perhaps the prototypical example of contemporary unsecured consumer debt is credit card borrowing. ${ }^{47}$ Such borrowing takes the form of credit card balances carried over from month to month. ${ }^{48}$ Although credit cards can be used simply as a form of payment, 75 percent of Americans who own credit cards ${ }^{49}$ use them as a means of borrowing money. ${ }^{50}$

Given the extraordinary willingness of Americans to mortgage their homes in exchange for cash, ${ }^{51}$ as evidenced by the boom in home equity loans, it is puzzling that so many lenders are willing to lend such vast amounts without requiring some form of collateral. ${ }^{52}$ The mystery is not explained by industry specialization, as many banks ${ }^{53}$ that engage in mortgage lending also issue credit card debt. ${ }^{54}$ Even more mysterious is the fact that, in contrast to unsecured lending to businesses, ${ }^{55}$ lenders in the consumer context are increasingly willing to offer unsecured loans to risky borrowers. ${ }^{56}$ Indeed, especially when compared to a generation ago, when loan officers met in person with potential borrowers, modern day credit card solicitations seem completely irrational, targeting those who have recently filed for bankruptcy, ${ }^{57}$ high school students, ${ }^{58}$ and family pets. ${ }^{59}$

\footnotetext{
${ }^{47}$ As of 2000, 76 percent of American households had at least one credit card. MANNING, supra note 44, at $6 \mathrm{n} .11$ (This figure refers to "bank" or all-purpose credit cards.) Manning also notes that the average number of cards per cardholder is ten (including bank, retail, phone, gasoline and travel and entertainment cards). Id. at 6. See also Bar-Gill, supra note 44, at 1384 (stating, on the basis of a 1995 study, that $80 \%$ of American households have at least one credit card).

${ }^{48}$ SULLIVAN ET AL., supra note 44, at 110-111.

${ }^{49} \mathrm{Id}$.

${ }^{50}$ Shockingly, the average credit card debt per individual is $\$ 12,500$. Bar-Gill, supra, note 44 , at 1385 .

${ }^{51}$ Obviously, renters cannot mortgage their homes, but as of 2004, 69\% of Americans owned their homes. U.S. Census Bureau, Housing Vacancies and Homeownership, Annual Statistics: 2004, http://www.census.gov/hhes/www/housing/hvs/annual04/ann04t12.html. Banks can certainly favor such borrowers or require some form of collateral in lieu of a home.

${ }^{52}$ In contrast, as recent studies show, the decision by borrowers to choose credit card borrowing over secured borrowing is rational despite the legal disadvantages to the borrower. See, e.g., Ronald J. Mann, Credit Card Policy in a Globalized World, Law and Economics Working Paper No. 018 (2004), available at http:// ssrn.com/abstract=509063; Bar-Gill, supra note 44; Laurie A. Lucas, Integrative Social Contracts Theory: Ethical Implications of Marketing Credit Cards to U.S. College Students, 38 AM. Bus. L.J. 413 (2001); Todd J. Zywicki, The Economics of Credit Cards, 3 CHAP. L. REV. 79 (2000); KLEIN, supra note 44; MEDOFF \& HARLESS, supra note 44; LEWIS MANDELL, THE CREDIT CARD INDUSTRY: A HiSTORY (1990).

${ }_{53}$ The list includes major national banks. See MANNING, supra note 44, at 95 ("[T]he most distinguishing feature of the credit card industry is its recent concentration. . . Today, the top ten card issuers control nearly 77 percent of the card market and 69 percent of the $\$ 1.2$ trillion in 1999 charge volume. . . Indeed, industry mergers and acquisitions have reduced the number of major corporate players and thus contributed to the costly increase in consumer banking services in general ... and credit card finance charges and fees in particular.").

${ }^{54}$ Delinquency on Consumer Loans: Hearing Before the House Comm. on Banking and Fin. Services, 104th Cong. (1996) (statement of Eugene A. Ludwig, Comptroller of the Currency), available at 1996 WL 520181). See, e.g., Nordstrom Bank Homepage, http://about.nordstrom.com/aboutus/credit/credit.asp?origin=footer.

${ }_{55}$ Professor Mann's empirical work has helped to explain the puzzle of unsecured lending to businesses. Mann, Explaining the Pattern, supra note 6.

${ }^{56}$ SULLIVAN ET AL., supra note 44, at 135-136; Robinson \& Healy, supra note 42.

${ }^{57}$ SULLIVAN ET AL., supra note 44, at 322 n.47.

${ }_{58}^{58} I d$. at 137.

${ }^{59}$ Id. at 322 n.90 ("During the hearings of the National Bankruptcy Review Commission on consumer bankruptcy, one of the commissioners noted that his dog Bradley had recently received a credit application.”).
} 
Why do credit card companies do it? Gains from high interest rates, various penalty fees and sheer volume all play important roles. ${ }^{60}$ But in my view, the critical factor is the creation of a new kind of collateral out of a system, namely credit reporting, that originally was intended for a quite different purpose, namely as a means of solving information asymmetries. ${ }^{61}$ I argue that credit card lenders are using human worth as an extremely valuable form of collateral, but that the law has not yet recognized this new collateralization.

\section{Collateralization through the mechanism of credit reporting}

The mechanism by which credit card lenders have been able to collateralize human worth is credit reporting. As described by the Fair Credit Reporting Act (FCRA), the federal statute that governs credit reporting, it is "[a]n elaborate mechanism ... for investigating and evaluating the credit worthiness, credit standing, credit capacity, character, and general reputation of consumers." ${ }^{62}$ Credit reporting is used by, among others, the "banking system,"63 lenders in the context of considering applications for home and personal loans, potential employers, insurance agencies, and anyone else who "otherwise has a legitimate business need for the information"64 Specifically, these institutions use credit reports to

\footnotetext{
${ }^{60}$ Indeed, Professors Sullivan, Warren and Westbrook conclude that "delinquent card holders who pay high interest [are] the most valued customers in the business." Id. at 135.

${ }^{61} 115$ Cong. Rec. 33408, 33408 (1969) ("With the growth of consumer credit, a vast credit reporting industry has developed to supply credit information."); Susan Block-Lieb \& Edward J. Janger, The Myth of the Rational Borrower: Rationality, Behavioralism, and the Misguided "Reform" of Bankruptcy Law, 84 TEX. L. R. 1481, 1514 (2006) ("In sum, credit scoring models have reduced the informational asymmetries between borrowers and lenders who are complete strangers to each other.").

${ }^{62} 15$ U.S.C. $\$ 1681(\mathrm{a})(2)(2005)$.

63 "Inaccurate credit reports directly impair the efficiency of the banking system, and unfair credit reporting methods undermine the public confidence which is essential to the continued functioning of the banking system." 15 U.S.C. $\S 1681(a)(1)(2005)$.

${ }^{64} 15$ U.S.C. $§ 1681 b(a)(3)(F)(2005)$. In its entirety, § 1681b(a) states: In general

Subject to subsection (c) of this section, any consumer reporting agency may furnish a consumer report under the following circumstances and no other:

(1) In response to the order of a court having jurisdiction to issue such an order, or a subpoena issued in connection with proceedings before a Federal grand jury.

(2) In accordance with the written instructions of the consumer to whom it relates.

(3) To a person which it has reason to believe--

(A) intends to use the information in connection with a credit transaction involving the consumer on whom the information is to be furnished and involving the extension of credit to, or review or collection of an account of, the consumer; or

(B) intends to use the information for employment purposes; or

(C) intends to use the information in connection with the underwriting of insurance involving the consumer; or

(D) intends to use the information in connection with a determination of the consumer's eligibility for a license or other benefit granted by a governmental instrumentality required by law to consider an applicant's financial responsibility or status; or
} 
determine whether or not to transact business with (most prominently in the form of issuing credit to) individuals.

The "system" consists rather simply of a "consumer report,"65 defined by the Act as "any written, oral, or other communication of any information by a consumer reporting agency bearing on a consumer's credit worthiness, credit standing, credit capacity, character, general reputation, personal characteristics, or mode of living which is used or expected to be used or collected in whole or in part for the purpose of serving as a factor in establishing the consumer's eligibility" for credit, insurance and the other purposes stated in the Act. ${ }^{66}$ While the statutory definition of a credit report is quite broad, the typical credit report is a simple document, essentially a list of debts (including credit cards, student loans and mortgage loans) and similar financial obligations of an individual, and a record of the individual's timeliness in meeting those obligations, ${ }^{67}$ over a certain period of time. ${ }^{68}$ A new industry of credit reporting agencies ${ }^{69}$ has developed to create and maintain these reports. ${ }^{70}$ These agencies regularly receive information necessary to compile credit reports from an individual's creditors, ${ }^{71}$ and, when requested by a potential creditor (or other interested party as defined by the FCRA), provide that information to potential

(E) intends to use the information, as a potential investor or servicer, or current insurer, in connection with a valuation of, or an assessment of the credit or prepayment risks associated with, an existing credit obligation; or

(F) otherwise has a legitimate business need for the information--

(i) in connection with a business transaction that is initiated by the consumer; or

(ii) to review an account to determine whether the consumer continues to meet the terms of the account.

${ }^{65}$ Throughout this article, I use the terms "consumer report" and "credit report" interchangeably.

${ }^{66} 15$ U.S.C. $§ 1681 \mathrm{a}(\mathrm{d})(1)(2005)$.

${ }^{67}$ The three major credit reporting agencies define a credit report as follows. "A report that a prospective lender or employer obtains from a consumer reporting agency that displays the manner in which a consumer has met his or her past credit obligations. It is used to help determine creditworthiness of the potential borrower." Equifax, Equifax Learning Center, Glossary of Terms, Credit report, https://www.econsumer.equifax.com/consumer/sitepage.ehtml?forward=elearning_glossary\#letterc. "Your credit report is divided into six main sections: consumer information (address, birthday and employment), consumer statement, account histories, public records, inquiries and creditor contacts. When you open a new account, miss a payment or move, these sections are updated with new information." TransUnion, TrueCredit, Credit reporting 101, Your credit report, http://www.truecredit.com/help/learnCenter/creditBasics/creditReporting101.jsp. "Your personal credit report contains: Federal district bankruptcy records and state and county court records of tax liens and monetary judgments. This information comes from public records. Specific information about each account, such as the date opened, credit limit or loan amount, balance, monthly payment and payment pattern during the past several years. This information comes from companies that do business with you." [The other categories listed by Experian are: personal data, inquiries, and statements of disputes by consumer and creditors.] Experian, Credit report basic FAQs, What information is included in my credit report?, http://www.experian.com/consumer/credit_report_faqs.html.

${ }^{68}$ Generally, adverse information may appear on a consumer credit report for no more than seven years. See 15 U.S.C. $\S 1681$ (c) (2005). In the case of Chapter 11 bankruptcy, adverse information may be reported for ten years. $I d$.

${ }^{69}$ I use the terms "credit reporting agencies," "consumer reporting agencies" and CRAs interchangeably.

70 "Consumer reporting agencies have assumed a vital role in assembling and evaluating consumer credit and other information on consumers." 15 U.S.C. $§ 1681$ (a)(3) (2005). There are three large national credit reporting agencies (CRAs), often referred to as "The Big 3": Equifax, Experian and TransUnion.

${ }^{71}$ See 15 U.S.C. $§ 1681 \mathrm{~s}-2(2005)$. 
creditors. $^{72}$

The original purpose of credit reporting was to provide information about consumer borrowers to banks who were not located in the borrowers' neighborhoods (indeed, they often were in other states) and thus did not know the borrowers' reputations. ${ }^{73}$ These banks needed a substitute for local loan officers who could track down reputational information by talking to employers, neighbors, and others who knew their borrowers more intimately. ${ }^{74}$ Credit reports filled the need, substituting credit scores for loan officers' assessments. ${ }^{75}$ In so doing, credit reporting allowed the banking system to nationalize; it is now typical for banks to loan money by means of credit cards to consumers across the country rather than just in the state in which the banks are located. ${ }^{76}$ Without question, credit reports solve information asymmetries, immeasurably increasing the ease with which lenders can determine the creditworthiness of individuals, and lowering the costs of doing so. ${ }^{77}$ Thus, what we should see is more careful and accurate underwriting, albeit to a broader range of borrowers.

What we see instead is lenders sending solicitations to family pets. I posit that this trend is partially explained by the fact that credit reports serve a second function more powerful than information transmission about borrower creditworthiness. They also constrain borrower behavior so successfully that they effectively create a form of collateral that is capable of liquidation. This additional function grows directly out of the information gathering function of credit reports. As I have described, the nationalizing market for credit demanded a system that could provide information about any individual in the country at a low cost. The triumph of credit reports in solving informational asymmetries is in their "universal coverage" of all consumer loan transactions in the country. ${ }^{78}$ Through a combination of public records and extensive private reporting from lenders

\footnotetext{
72 15 U.S.C. $\$ 1681 b(2005)$.

${ }^{73}$ Block-Lieb \& Janger, supra note 61, at 1509.

${ }^{74} \mathrm{Id}$.

${ }^{75} I d$. at $1509-14$.

${ }^{76}$ Id. See also Elizabeth R. Schiltz, The Amazing, Elastic, Ever-Expanding Exportation Doctrine And Its Effect On Predatory Lending Regulation, 88 MinN. L. REV. 518, 540-556 (2004).

77 The ease of access to information contained in credit reports serves to lower overall transaction costs to lenders -- a benefit which is theoretically passed on to consumers in the form of lower interest rates and more available credit. As described by former Chairman of the Board of Governors of the Federal Reserve System Alan Greenspan: "[W]ithout the information that comes from various credit bureaus and other sources, lenders would have to impose an additional risk premium because of the uncertainty before they make such loans or may, indeed, choose not to make loans at all. So it is clearly in the interest of consumers to have information flowing continuously into these markets. It keeps credit available to everybody, including the most marginal buyers. It keeps interest rates lower than they would otherwise be because the uncertainties which would be required otherwise would not be there." Remarks following testimony by Alan Greenspan, April 30, 2003, House Financial Services Committee.

${ }^{78}$ Block-Lieb \& Janger, supra note 61, at 1511.
} 
and other creditors, ${ }^{79}$ credit reporting agencies can provide comprehensive, accurate, ${ }^{80}$ and succinct information about consumers' borrowing behavior. $^{81}$ Indeed, in the case of the credit market, the system works so well that it is rare for lenders not to order credit reports about prospective borrowers. Thus, a potential borrower has very little ability to prove her character to a bank other than to ensure that this list of financial obligations is generally positive. ${ }^{82}$

The result is that credit reports have effectively monopolized the market for information about borrower behavior. The omnipresence of the credit reporting system is the key to its power as a mechanism for behavior modification. Because lenders rely so heavily on credit scores in making underwriting decisions, a bad credit score has significant consequences. Certainly, such consequences can include the loss of an opportunity to buy a home, rent an apartment, or receive a loan. ${ }^{83}$ When an individual uses her personal credit history to support her business enterprise, as in the case of providing a personal guaranty for a business loan, such consequences can extend even further. It seems fair to say that a good credit score is often essential to an individual's ability to generate wealth, be it from employment, credit, or ownership of assets.

Moreover, studies of credit card use find a strong link between credit cards and the purchase of both basic and "luxury" ${ }^{84}$ consumer goods and

\footnotetext{
${ }^{79}$ See supra note 67.

${ }^{80}$ I use the term "accurate" here to describe completeness of information rather than accuracy in predicting how creditworthy an individual is. There is much evidence, however, that this information is also quite useful for the latter purpose. See Robert B. Avery, et al., Credit Report Accuracy and Access to Credit, Federal ReSERVE BULLETIN 297 (2004) ("[F]actors ... used in credit scoring models are the ones proven statistically to be the most valid predictors of future credit performance."). See also Gary G. Chandler \& Lee E. Parker, Predictive Value of Credit Bureau Reports, 4 Journal Of RETAIL BANKING 47 (1989). Of the factors most commonly employed in assessing a consumer's credit risk, past payment history is traditionally given the greatest proportional weight, reflecting the assumption that past behavior is indicative of future performance. Fair Isaac Corporation, What's In Your Score, www.myfico.com.

${ }^{81}$ CRAs report on other behavior too, but I am focusing here on borrowing.

${ }^{82}$ The consequences described by plaintiffs in FCRA cases provides ample evidence of the importance of credit reports in obtaining loans, credit cards and other commercial opportunities. In Stevenson v. TRW Inc., 987 F.2d 288, 297 ( $5^{\text {th }}$ Cir. 1993), for example, plaintiff was "was denied credit three times during TRW's reinvestigation: by Bloomingdale's, by Bank One, and by Gabbert's Furniture Company" and ultimately had to seek credit from a bank whose president was a friend (and thus could review the plaintiff's creditworthiness more holistically). See also Thompson v. San Antonio Retail Merchants Ass'n, 682 F.2d 509, 514 (5th Cir. 1982) (plaintiff denied credit three times due to negative credit report); Millstone v. O'Hanlon Reports, Inc., 528 F.2d 829, 834-35 (8th Cir.1976) (plaintiff was refused insurance on grounds of negative credit report); Boris v. Choicepoint Services, Inc., 249 F. Supp.2d 851, 855 (W.D. Ky. 2003) (same). These cases are representative of the innumerable occasions when consumers are denied credit on the basis of a negative report.

${ }^{83}$ See, e.g. Getting Credit: What You Need to Know About Your Credit, Federal Trade Commission Publication, http://www.ftc.gov/bcp/conline/pubs/credit/gettingcredit.htm ("Bad credit ... means that you might have trouble getting a car loan, a credit card, a place to live and, sometimes, a job."); Roger D. Blair \& Virginia Maurer, Statute and the Common Law: The Fair Credit Reporting Act, 49 Mo. L. Rev. 289, 295 (1984) (A negative credit report "may result in an inability to obtain credit, employment, or insurance."). See also JoHN R. VACCA, IDENTITY THEFT 8-9 (2003).

${ }^{84}$ I use the term "luxury" to distinguish these goods from those that implicate survival, but, as the list below
} 
services. Goods in the first category include groceries, ${ }^{85}$ tuition, ${ }^{86}$ and clothing. ${ }^{87}$ These are the kinds of things purchased by credit card users who do not have the resources to make ends meet month to month. ${ }^{88}$ Goods in the second category include fitness club memberships, restaurant meals, and vacations. ${ }^{89}$ These are the kinds of things that contribute to middle class lifestyle and status. Because many people pursue lifestyles for which they cannot afford to pay with their income alone, they need credit to buy statusenhancers. $^{90}$ In other words, an individual with bad credit loses the things that are important to both her economic and social status. ${ }^{91}$

It is understandable, therefore, that borrowers go to great lengths to pay their credit card and other unsecured debts voluntarily, despite the arguable irrationality of paying fees so exorbitant that they regularly result in negative amortization. ${ }^{92}$ It is also predictable that most Americans regulate their own behavior in ways that maximize their credit scores. Such regulation certainly includes taking fewer risks (which I will call constraining behavior), but it also includes incurring debts that may be seen as improving one's credit score (which I will call shaping behavior). ${ }^{93}$

Thus, while the law recognizes and regulates the information transmission function of credit reports, the credit card industry has begun to capitalize on the connection between credit and status. From its marketing tactics, it appears that the industry no longer relies on the information

\footnotetext{
suggests, they are often not extravagant.

${ }^{85}$ Peter Lucas, Letting the Numbers Tell the Story, 11 TeChNOLOGY, at 36; Elizabeth Dunne Schmitt, Does Rising Consumer Debt Signal Future Recessions?, 28 ATLANTIC ECON. J., at 333; Paul Lim et al., Digging Your Way Out of Debt, 130 U.S. NEWS \& WORLD REP., at 52.

${ }^{86}$ SULLIVAN ET AL., supra note 44, at 138.

${ }^{87} I d$. at 111 .

${ }^{88}$ See Lucas, supra note 85 at 36. But see Todd Zywicki, An Economic Analysis of the Consumer Bankruptcy Crisis, 99 NORTHWESTERN UNIV. L. R. 1463, 1494 (2005) (acknowledging the increase in credit card debt of lower-income borrowers, but arguing that such debt does not increase their overall debt burden because it substitutes for debt to pawnbrokers, rent-to-own retailers and the like).

${ }^{89} \mathrm{Lim}$, supra note 85 , at 52.

${ }^{90} \mathrm{Id}$. at 52 .

${ }^{91}$ Indeed, there appears to be a growing trend of using credit reports as a proxy for screening and decisionmaking processes outside the context of credit transactions, and in contexts where character was once assessed in a more holistic manner. For instance, some relationship experts now recommend using credit reports to evaluate the trustworthiness and suitability of a potential romantic partner, while some businesses forego the interview screening process entirely in favor of the information about an individual that may be gleaned from a credit report. See Stacy A. Teicher, Judged by the Content of Your Credit Report, THE Christian SCIENCE Monitor, March 1, 2004.

${ }^{92}$ A recent news report defines negative amortization on credit card debt as a circumstance where "an individual's debt continues to grow even though she is making payments on it." Kathleen Day \& Caroline E. Mayer, Credit Card Penalties, Fees Bury Debtors, Washingtonpost.com, http://www.washingtonpost.com/ac2/wp-dyn/A10361-2005Mar5?language=printer.

${ }^{93}$ The Fair Isaac Corporation, creator of the FICO scores used widely in credit reports, recommends the following for those managing new credit: "In general, having credit cards and installment loans (and paying timely payments) will raise your score. Someone with no credit cards, for example, tends to be higher risk than someone who has managed credit cards responsibly." The Fair Isaac Corporation, MyFico, Improving Your FICO Score, http://www.myfico.com/CreditEducation/ImproveYourScore.aspx.
} 
provided by credit scores as a means to screen borrowers. Instead, the industry uses credit scores as a threat by taking advantage of their tremendous importance to American consumers. The result is a cycle of increasing debt, accompanied by more powerful behavior control: Credit card lenders offer credit extensively with the knowledge that people use credit to enhance their status and wealth. People take on more credit card debt, thereby accepting the behavioral constraints that are required to maintain a good credit score. And the self-regulation required to maintain a good credit score frees the industry to offer even more credit at costs that are extremely low because the need for careful screening no longer exists.

It could be argued that, to the extent credit card lenders are collateralizing something, it is the lost consumer goods, insurance and employment that serve as collateral. Common experience suggests, however, that something deeper is lost. Consider the awkwardness of having to pay cash for an expensive pair of shoes. Or of trying to rent a car without a credit card. Indeed, while this new collateralization clearly implicates reputational concerns, ${ }^{94}$ it appears to go deeper, as I will discuss in greater detail in Part III.

As plaintiffs' testimony in lawsuits against credit bureaus for negligent maintenance of credit reports shows, the real loss to consumers does not seem to be the loss of goods but rather the loss of face. Plaintiffs describe feelings of "humiliation," "considerable embarrassment," 96 "terrific shock," 17 and "loss of reputation." "98 Courts have broadly recognized the harm to a plaintiff claiming a FCRA violation, by allowing damages for emotional distress in addition to the actual damages proven by plaintiffs. ${ }^{99}$

\footnotetext{
${ }^{94}$ On this point, see James Q. Whitman, The Two Western Cultures of Privacy: Dignity versus Liberty, 113 YALE L. J. 1151 (2004).

${ }^{95}$ See, e.g., Morris, 563 F. Supp. at 967; Cousin v. TransUnion Corp., 246 F.3d 359, 369 n.15 (5 ${ }^{\text {th }}$ Cir. 2001); Boris v. Choicepoint Services, Inc., 249 F. Supp.2d 851, 860 (W.D. Ky. 2003); Collins v. Retain Credit Company, 410 F. Supp. 924, 932 (E.D. Mich. 1976).

${ }^{96}$ Stevenson, 987 F.2d at 297.

${ }^{97} \mathrm{Id}$.

${ }^{98}$ Dalton v. Capital Associated Industries, Inc., 257 F.3d 409, 418 (4 $4^{\text {th }}$ Cir. 2001).

${ }^{99}$ See Cousin v. TransUnion Corp., 246 F.3d 359, 369 n.15 (5 ${ }^{\text {th }}$ Cir. 2001) (actual damages, as provided for in 15 U.S.C. $§ 1681$ o, "may include damages for humiliation or emotional distress even if the consumer has suffered no out-of-pocket losses, as well as damages for injury to reputation and creditworthiness"), citing Fischl v. General Motors Acceptance Corp., 708 F.2d 143 ( $5^{\text {th }}$ Cir 1983); Dalton, 257 F.3d at 418 (recognizing that damages for "emotional distress and loss of reputation" may be awarded for the circulation of false information contained within a credit report, even where the false information itself did not cause direct adverse employment consequences to the plaintiff); Stevenson, 987 F.2d at 297 (plaintiff awarded damages after experiencing "terrific shock" and "considerable embarrassment" upon erroneously receiving a bad credit rating); Bryant v. TRW, Inc., 487 F. Supp. 1234, 1242-43 (E.D. Mich. 1980), aff'd, 689 F.2d 72 (6 ${ }^{\text {th }}$ Cir. 1982) (plaintiff awarded damages for mental anguish, embarrassment and humiliation after a credit reporting agency furnished inaccurate mortgage reports pertaining to plaintiff); Millstone v. O'Hanlon Reports, 528 F.2d 829, 834 (8 ${ }^{\text {th }}$ Cir. 1976); (where a credit reporting agency willfully reported false negative information in violation of the FCRA, damages for mental anguish are appropriate); Boris v. Choicepoint Services, Inc., 249 F. Supp.2d 851, 860-861 (W.D. Ky. 2003) (plaintiff awarded damages for "humiliation, mental distress and embarrassment" after a credit reporting agency
} 
In summary, what began as a by-product of information transmission has resulted in a remarkable transformation in the availability of consumer credit. Some time between 1950, when credit card debt meant buying a washing machine on credit from Sears, ${ }^{100}$ and now, when credit card solicitations offer literally hundreds of thousands of dollars in credit per year to every American household, ${ }^{101}$ credit became easy to come by without proof of any financial basis for repayment. Whether accidentally or not, credit card lenders now use credit reports for a purpose much more powerful than screening borrowers. They use credit reports to collateralize human worth. ${ }^{102}$

\section{Human worth as collateral}

There is nothing new or surprising about this description of the power of credit scores. But because the law draws such a bright line between secured and unsecured credit, it may seem surprising that, by constraining behavior so well, the credit reporting system effectively creates collateral. The purpose of this section, therefore, is to compare the credit reporting system's use of human worth as collateral against the features of collateral established in the literature on secured lending. As I will show, consumer

circulated a credit report containing inaccurate insurance claim information); Collins v. Retain Credit Company., 410 F. Supp. 924, 932 (E.D. Mich. 1976) (plaintiff awarded damages for "loss of reputation, embarrassment and humiliation" after being denied auto insurance on the basis of statements in her credit report "regarding her alleged excessive drinking habits and alleged instances of low moral character"); Morris v. Credit Bureau of Cincinnati, 563 F. Supp. 962, 969 (S.D. Ohio 1983) (where credit reporting agency reported erroneous information about plaintiff's credit, plaintiff was entitled to damages for the "significant injury to his reputation, his family, his work and his sense of well-being as a proximate result of defendant's negligent failure to comply with the FCRA").

${ }^{100}$ SULLIVAN ET AL., supra note 44, at 109.

${ }^{101} I d$. at 109 .

${ }^{102}$ It is important to note that, from an economic perspective, the collateralization of human worth does in fact solve information asymmetries. It does so by substituting collateral for information. For discussions of the ways in which collateral solves information problems in imperfect markets, see Mann, Explaining the Pattern, supra note 6, at 638 ("[T] he advantages that a lender receives from a grant of collateral can lower the lender's anticipated overall costs and thus indirectly lower the costs that the borrower must pay to induce the lender to make the loan."); Hylton, supra note 17, at 214 (collateral aligns borrower and lender incentives, which in turn mitigates the problem of "moral hazard", i.e. the tendency of borrowers to fail to maximize the probability of loan repayment); Lan Cao, Looking at Communities and Markets, 74 NOTRE DAME L. Rev. 841, 852, 856-857 (1999) (absence of collateral increases transaction costs and can result in "rational redlining", i.e., "those who need money the most are those who can borrow the least"); Jameel Jaffer, Microfinance And The Mechanics Of Solidarity Lending: Improving Access To Credit Through Innovations In Contract Structure, 9 J. TRANSNAT'L L. \& POL'Y 183, 189 (1999) ("[C]ollateral can often compensate for some of the gap in information between lender and borrower, providing a way to both increase the borrower's stake in the success of the project and reduce losses to the bank in the event of a default."); WiLliam SimON, THE COMMUNITY ECONOMIC DEVELOPMENT Movement: LAW, Business \& THE New SOCIAL PoliCy 44-45 (2001) ("To the extent that an applicant can post assets as security for loan commitments, the lender has less need to rely on assessments of her reliability. Assets perform an informational role, as well. An applicant who puts her own assets at risk by investing in a house or business or in training that fits her for particular jobs signals to others the seriousness of her belief that the investment is a sound one and her intention to act to make it work. Poor people are less able to substantiate their commitments in this way."). 
lenders are using human worth in a way that closely approximates the prototypical use of collateral. Again, my point in analyzing human worth as collateral is not to challenge the distinction between secured and unsecured lending. ${ }^{103}$ Rather, my point is that lenders have discovered a new form of leverage in a world where credit is extremely important to status and wealth. In order to emphasize the economic value to lenders of this new leverage, I describe it as collateral. But whether the leverage actually constitutes collateral or is a substitute for collateral is, for my purposes, less important than that the law fails to recognize it more than in passing. ${ }^{104}$

\section{a. Quantifiable}

As described in Part I, in order for something to serve as collateral, it must be quantifiable. If human worth is to serve as collateral, it must have a value that can be compared among different "owners" of this asset, thereby allowing a lender both to choose among borrowers and to establish loan terms that will sufficiently protect the lender's interests. In the consumer credit context, one means of quantification is an individual's credit score. Lenders do in fact use this score to make underwriting decisions. As I have discussed, because credit scores link so extensively to economic and social opportunities, they directly implicate human worth. Moreover, as FCRA lawsuits demonstrate, a good credit score itself is now something about which to be proud, and a bad credit score is something about which to be ashamed. ${ }^{105}$ In this sense, pride and shame are calibrated by means of credit scores. ${ }^{106}$

\section{b. Capable of liquidation}

For the purposes both of motivating the borrower to repay voluntarily and providing a means of collecting cash upon foreclosure or repossession, collateral also must be capable of liquidation. In the consumer context, the connection between credit reports, credit, and social status provides a means of liquidating a person's sense of honor. Simply put, by reporting negative information to a credit bureau, a lender can limit a borrower's acquisition of status-enhancing goods and services, and more basically, lower her social

\footnotetext{
${ }^{103}$ Nonetheless, a few prominent scholars have recognized that the line is arguably more formal than operational, and more important in the law than in transactional behavior. See, e.g., LoPucki, supra note 7, at 1926.

${ }^{104}$ It is, of course, of great pragmatic importance ultimately to determine whether the law should treat this new leverage as collateral or as something else.

${ }^{105}$ See supra notes 95-99 and accompanying text.

${ }^{106}$ It could also be said that the money damages for emotional distress that plaintiffs have received for violations of the FCRA are a means of quantifying human worth in this context.
} 
standing. Here too, the FCRA lawsuits provide powerful evidence that people who lose credit or employment opportunities, or who simply are publicly perceived as having bad credit suffer a diminution of human worth. Credit card companies can and do control the potential for liquidation by providing credit bureaus with information about defaults. In this way, credit bureaus can diminish a person's sense of self worth.

\section{c. Capable of appreciation}

When collateral has the potential to appreciate over time, it is generally more attractive to a lender. As I have discussed, American consumers can modify their purchasing habits to increase their credit scores. ${ }^{107}$ In this respect, we can manage this particular asset's appreciation in value. Appreciation is useful to credit card lenders in the traditional respects, for example by raising the stakes more for borrowers so that they will limit their risky behavior. But this particular means of causing appreciation is also quite useful because it encourages borrowers to borrow even more than they would if incentivized differently.

\section{d. Meaningful to borrower}

To ensure voluntary repayment and constrain behavior, collateral should be meaningful to the borrower. Obviously, by collateralizing human worth, lenders have found a means by which to access something even more meaningful than a home or a wedding ring. They have found a way to constrain borrowers' ability to obtain future credit, status enhancing goods and services, and wealth. Indeed, it is difficult to imagine a more meaningful asset.

\section{e. Easy to monitor}

Collateral that is easy to monitor is attractive to lenders because it reduces the cost of lending. The ease with which information is transmitted in the credit reporting system makes human worth as collateral extremely easy to monitor. By reviewing the patterns and details of payments and defaults, lenders can use credit reports to predict the extent to which an individual pegs her honor on her credit score. Thus, by capturing a sense of human worth in credit scores, lenders are able to monitor the collateral quite efficiently.

f. Transferable

${ }^{107}$ See supra note 93 and accompanying text. 
An important distinction between human worth as collateral and other forms of collateral is that human worth cannot be repossessed and sold for cash. Given the importance of repossession to the traditional theory of secured lending, this distinction is a strong rejoinder to my hypothesis that lenders are using human worth as collateral. As recent empirical scholarship details, however, lenders regularly take security interests in software and other intellectual property which cannot practically be repossessed. $^{108}$ These things are nonetheless recognized by the law as collateral, lending support to the idea that modern-day secured lending, if economically rational, provides important benefits other than serving as a means of payment collection.

\section{Law's Irrelevance}

Although I am confident that the phenomenon I have identified as the collateralization of human worth exists, I want to be clear that, at present, my analysis of what caused this phenomenon is merely an untested hypothesis. The purpose of this sub-section and of Part II.B.3 is to suggest that the law was largely irrelevant to the creation of this new collateral; the purpose of Part IV is to suggest that the globalizing credit market was the driving force. I hope that others will find analogs in their own work that will help to test the more exploratory parts of this analysis.

Before considering the extent to which the law fails to recognize credit card lenders' use of human worth, it might be useful to consider how the law could have recognized this new use. One possibility would simply be a statutory or judicial recognition that Article 9 intangibles can include concepts of self worth, which as I discuss below, are not extraordinarily different from good will. Another would be for the FCRA explicitly to recognize that human dignity is at stake in modern lending practices and to protect consumers from over-reaching by lenders in their use of this new collateral. My preliminary review, however, shows at most marginal legal recognition of human worth's new market value.

\section{a. Article 9 intangibles}

Even though human worth, as used by credit card lenders, has many of the features of collateral, secured transactions law fails entirely to recognize

\footnotetext{
${ }^{108}$ Mann, Software Financing, supra note 9. Lack of transferability is arguably a problem for all nonphysical collateral. In this context, though, the inability to obtain future credit is arguably a form of repossession, a point which I am grateful to Professor Hillinger for sharing.
} 
human worth as collateral. The reason cannot be lack of specificity. ${ }^{109}$ On the one hand, as we have seen, credit reporting provides a very specific means of quantifying human worth. ${ }^{110}$ On the other, the law permits collateralization of things as intangible as intellectual property and good will, ${ }^{111}$ among other "general intangibles."112 Even in the consumer context, ${ }^{113}$ "things in action," 114 so long as they are specifically enough described, ${ }^{115}$ can be collateralized. ${ }^{116}$

Qualitatively, good will and things in action might be the most similar to human worth. The former signifies notions of name recognition and customer loyalty, but traditionally it has been an asset of businesses rather than individuals. ${ }^{117}$ The latter includes torts, ${ }^{118}$ though it is unclear whether a tort based on violation of the Fair Credit Reporting Act has ever actually been claimed as collateral. However, neither of these categories captures credit card lenders' extensive use of human worth itself as the basis for managing borrower behavior, incentivizing voluntary repayments, and reducing lender costs.

A useful analogy to the possible legal recognition of human worth as collateral is real estate law's historical protection of borrowers who mortgage their homes. ${ }^{119}$ Rights of redemption, ${ }^{120}$ voiding of contract

\footnotetext{
${ }^{109}$ Perhaps the law's failure here is due in part to its abhorrence of anything that implicates involuntary servitude.

${ }^{110}$ See supra notes $105-106$ and accompanying text.

${ }^{111}$ See supra notes 19-21 and accompanying text.

${ }^{112}$ U.C.C. § 9-102(a)(42) (2005) (“'General intangible' means any personal property, including things in action, other than accounts, chattel paper, commercial tort claims, deposit accounts, documents, goods, instruments, investment property, letter-of-credit rights, letters of credit, money, and oil, gas, or other minerals before extraction. The term includes payment intangibles and software.").

${ }^{113}$ I base this conclusion on the fact that Article 9 does not exclude "things in action" from the list of things that consumers can collateralize.

${ }^{114}$ I.e., rights that can be recovered by a law suit. 63 Am. Jur. 2d Property $\S 22$ (1997).

${ }^{115}$ See supra note 29.

${ }^{116}$ U.C.C. § 9-102(a)(42) (2005).

117 See J. Thomas McCarthy, MCCARthy on Trademarks AND Unfair Competition, $§ 2: 19$ (4th ed. 2002) (defining goodwill as "the intangible value of a business beyond the value of its physical assets"); Metro. Bank v. St. Louis Dispatch Co., 149 U.S. 436, 446 (1888) (defining good will as "the advantage or benefit, which is acquired by an establishment, beyond the mere value of the capital stock, funds or property employed therein, in consequence of the general public patronage and encouragement which it receives from constant or habitual customers, on account of its local position, or common celebrity, or reputation, for skill or affluence, or punctuality, or from other practical circumstances, or necessities, or even from ancient partialities or prejudices.").

${ }^{118}$ Lars S. Smith, General Intangible or Commercial Tort: Moral Rights and State-Based Intellectual Property as Collateral under U.C.C. Revised Article 9, 22 EMORY BANKR. DEV. J. 95, 108 (2005). "Things in action" do not include commercial torts, however. Id.

${ }^{119}$ For a discussion of consumer protections in real estate law, see Rashmi Dyal-Chand, From Status to Contract: Evolving Paradigms for Regulating Consumer Credit, _ TENN. L. REV _ (forthcoming 2006) (manuscript on file with author).

${ }^{120}$ For discussions of the equity of redemption, see NELSON \& WHITMAN, supra note 8, at $\$ 3.1$; GEORGE E. Osborne, MorTGages, 13 (2d. ed. 1970); Morris G. Shanker, Will Mortgage Law Survive?: A Commentary and Critique on Mortgage Law's Birth, Long Life, and Current Proposals for Its Demise, 54 CASE W. RES. L. REV. 69 (2003); Marshall E. Tract, Renegotiation and Secured Credit: Explaining the Equity of Redemption, 52 VAND. L. REV. 599 (1999). For discussions of the statutory right of redemption, see NELSON \& WHITMAN, supra note 8, at
} 
language, ${ }^{121}$ and use of parol evidence ${ }^{122}$ all arguably recognize the unique feelings of attachment to one's home, an attachment that Margaret Jane Radin describes as embodying personhood. ${ }^{123}$ Qualitatively, the ways in which mortgage lenders rely on borrowers' attachment to their homes to manage borrower behavior is very similar to the ways in which credit card lenders rely on human worth. What distinguishes the two, however, is that in the former context, the physical home is still the explicit collateral, whereas in the latter, there is no physical collateral at all and yet lenders receive many of the same benefits as they do from taking security interests.

\section{b. Judgments, executions, and bill collectors}

When credit card lenders seek legal remedies for defaults by borrowers, they generally do not have the right to collect payment by means of repossession. In other words, the law considers them to be unsecured creditors who must reduce their claims to judgments in order to acquire a property interest in the borrower's assets. It should come as no surprise that in these lawsuits, a vast number of which are decided by arbitration, ${ }^{124}$ there is also no recognition of human worth as collateral. Instead, courts and arbitrators focus on contractual language concerning such matters as arbitration rights, ${ }^{125}$ and fees and penalties. ${ }^{126}$ Thus, for example, in Arriaga v. Cross Country Bank, ${ }^{127}$ the court refused to void an arbitration clause in the plaintiff's credit card contract despite her claim that she did not contest the clause because to do so would risk negative information on her credit report. In other words, the court did not recognize that the lender was using the borrower's human worth to constrain her behavior.

Credit card lenders, on the other hand, do seem to recognize the power of shaming their borrowers, though they may not explicitly describe it as such. Their shaming takes the form of aggressive and targeted bill collection techniques such as car repossessions ${ }^{128}$ and small claims

689-706; Korngold \& Goldstein, supra note 24, at 492-3; James B. Hughes, Jr., Taking Personal Responsibility: A Different View of Mortgage Antideficiency and Redemption Statutes, 39 ARIZ. L. REV. 117 (1997).

${ }^{121}$ See, e.g., McElroy v. Grisham, 810 S.W.2d 933 (Ark. 1991); Shadman v. O'Brien, 180 N.E. 532 (Mass. 1932); Scheibe v. Kennedy, 25 N.W. 646 (Wis. 1885); Campbell v. Dearborn, 109 Mass. 130, 12 Am.Rep. 671 (1872). See also OSBORNe, supra note 120, at 116; NELSON \& WhitMAn, supra note 8, at 58.

${ }^{122}$ See, e.g., Pierce v. Robinson, 13 Cal. 116, 125 (1859).

${ }^{123}$ Radin, Property and Personhood, supra note 25, at 991-992.

${ }^{124}$ See Jean R. Sternlight, Creeping Mandatory Arbitration: Is it Just?, 57 STAN. L. ReV. 1631 (2005).

${ }^{125}$ See, e.g., Taylor v. First North American National Bank, 325 F.Supp.2d 1304 (M.D. Ala. 2004); Arriaga v. Cross Country Bank, 163 F.Supp.2d 1189 (S.D. Cal. 2001); Bank One, N.A. v. Coates, 125 F.Supp.2d 819 (S.D. Miss. 2001); Edelist v. MBNA America Bank, 790 A.2d 1249 (Del. Super. 2001).

${ }^{126}$ See, e.g., Morris v. Redwood Empire Bancorp, 27 Cal.Rptr.3d 797 (Cal. Ct. App. 2005).

${ }^{127} 163$ F.Supp.2d 1189 (S.D. Cal. 2001).

${ }^{128}$ See generally Michael Rezendes \& Francie Latour, No Mercy for Consumers: Firms' Tactics are One Mark of System that Penalizes those who Owe, Boston Globe, August 1, 2006, 
lawsuits. $^{129}$

Perhaps the greatest recognition that human worth is at stake in the credit card lending context is the awards of damages for emotional distress suffered by plaintiffs alleging violations of the FCRA. Although these cases recognize the shame suffered by plaintiffs, by focusing on the negligent behavior of the credit bureaus they do not typically recognize the important role played by lenders in manipulating human worth. This failure is particularly interesting in light of the fact that the legislative history references the dissemination by credit bureaus of "highly sensitive and personal information" about a person's "general character." If this does not implicate human worth, it is hard to imagine what does.

The FCRA seeks to protect consumers, however, by protecting their privacy rather than their human worth. ${ }^{130}$ The greatest practical consequence of this different focus is that the FCRA provides consumers with the right to know what private information credit bureaus are sharing with others, but it does not really limit the use of that information by credit bureaus or lenders. ${ }^{131}$ It does not, for example, prohibit lenders from threatening diminution of human worth under certain circumstances. ${ }^{132}$ Thus, the FCRA regulates the way in which credit reports transmit information rather than the way in which they modify behavior. The consequence in the US is that the law recognizes human worth as at most marginally relevant. While the law recognizes the repercussions to consumers' rights of privacy, it does not recognize that the threat to personal reputation, or to the ability to borrow in the future, can themselves be potent forms of leverage.

\section{B. Peer Lending}

In a rural Bangladeshi village, the tale is told of a woman who, because

http://www.boston.com/news/special/spotlight_debt/part1/page1.html; Walter V. Robinson \& Michael Rezendes, Enforcers' Might Goes Unchecked, BOSTON GLOBE, August 1, 2006, http://www.boston.com/news/special/spotlight_debt/part3/page1.html.

${ }^{129}$ See generally Beth Healy, Dignity Faces a Steamroller: Small-Claims Proceedings Ignore Rights, Tilt to Collectors, BOSTON GlOBE, July 30, 2006, http://www.boston.com/news/special/spotlight_debt/part2/page1.html.

${ }^{130}$ The legislative history evidences the FCRA's focus on privacy. See, e.g., 116 Cong. Rec. 35941, 35941 (1970) ("The purposes of the Fair Credit Reporting Act are to give consumers a chance to correct inaccurate information in their credit file; to preserve the confidentiality of such information; and to prevent undue invasions of the individual's right to privacy."). 119.

${ }^{131}$ Elsewhere, I discuss this distinction at greater length. Dyal-Chand, From Status to Contract, supra note

\footnotetext{
132 The Fair Debt Collection Practices Act, 15 U.S.C. $\$ 1692$ (2005), arguably does limit the most egregious harassment by creditors, thus providing some circumstances in which the law protects borrower's dignity. But both because it limits only the worst behavior and because it applies to lender behavior after the initial choices regarding collateralization are made, this statute provides little protection in the world of this new collateralization.
} 
she was late in repaying her microloan from the Grameen Bank, was locked in a bank branch by fellow borrowers who were acting as guarantors of her loan. ${ }^{133}$ Faced with the loss of honor to her family as a result of her failure to repay, she used her sari to hang herself from the ceiling fan. ${ }^{134}$

The Grameen Bank makes tiny loans to poor, landless people (primarily women) in Bangladesh. ${ }^{135}$ The Bank's purpose in making these microloans is to provide the poor with the capital to start their own microenterprises. ${ }^{136}$ Part of the Bank's attraction to its funding sources and many others is that it presents itself as a "typical" commercial lender. ${ }^{137}$ Thus, when the Bank began lending to the landless poor, it faced an immediate problem: the poor have no physical collateral with which to secure their loans. ${ }^{138}$ They do, however, have their honor. So the Bank substitutes honor as collateral. The Bank is able to do this by means of an ingenious device called a solidarity circle. The Bank requires borrowers, as a condition to receiving a loan, to form groups of five. ${ }^{139}$ Each borrower within this circle must guaranty the loans of the other circle members. ${ }^{140}$

Given the extraordinary poverty of its borrowers, the Bank must be well-aware that they cannot actually pay each other's debts. ${ }^{141}$ Nonetheless,

${ }^{133}$ AMINUR RAHMAN, WOMEN AND MicrocREDIT IN RURAL BANGLADESH 75-76 (1999).

${ }^{134}$ Id. Rahman also found that the pressure to maintain the family's honor resulted in violence against women in the family. Id. at 120-121 (In his study village, 57\% of female borrowers reported an increase in "verbal aggression" after joining the Bank and an additional 13\% reported an increase in both "verbal aggression" and "physical assault."). See also Celia Taylor, Microcredit as a Model: A Critique Of State/NGO Relations, 29 SYRACUSE J. OF INT'L L. \& COM. 303, 327 (2002) ("[R]ather than 'empowering' poor women, loan circles can deepen poor women's enmeshment in traditional relationships of domination.").

${ }^{135}$ Grameen Bank Homepage, A short history of Grameen Bank, http://grameen-info.org/bank/hist.html; Grameen Bank Homepage, Grameen Bank, http://grameen-info.org/bank/index.html; Grameen Bank Homepage, Credit delivery system, http://grameen-info.org/bank/cds.html; AlEX COUNTS, GIVE Us CREDIT xiii (1996) (the loans are typically between twenty-five and seventy-five US dollars); DAVID BORNSTEIN, THE PRICE OF A DREAM 19, 26 (1996).

${ }^{136}$ Grameen Bank Homepage, Credit delivery system, http://grameen-info.org/bank/cds.html.

137 BornsteIn, supra note 135, at 231. See also Philip M. Nichols, A Legal Theory Of Emerging Economies, 39 VA. J. INT'L L. 229, 299-300 (1999) ("Grameen Bank acts in many respects as a typical commercial bank, albeit with a customer base consisting of the very poor of Bangladesh."); Lewis D. Solomon, Microenterprise: Human Reconstruction in America's Inner Cities, 15 HARV. J.L. \& PUB. POL'Y 191, 195 (1992) (Grameen Bank is like a "typical commercial bank.").

${ }^{138}$ Grameen Bank Homepage, Breaking the vicious cycle of poverty through microcredit, http://grameeninfo.org/bank/bcycle.html ("The Grameen Bank is based on the voluntary formation of small groups of five people to provide mutual, morally binding group guarantees in lieu of the collateral required by conventional banks."). See also Mohammad A. Auwal \& Arvind Singhal, The Diffusion of Grameen Bank in Bangladesh: Lessons Learned about Alleviating Rural Poverty, 14 KnOwledge: Creation, DifFusion, Utilization 7, 16 (1992) (stating that peer lending "replac[es] material collateral with a kind of social collateral"); RAHMAN, supra note 133, at 8 ("The pressure of the group acts as the collateral for the bank.").

${ }^{139}$ Grameen Bank Homepage, Credit delivery system, http://grameen-info.org/bank/cds.html.

${ }^{140}$ Grameen Bank Homepage, Breaking the vicious cycle of poverty through microcredit, http://grameeninfo.org/bank/bcycle.html; RAHMAN, supra note 133, at 78; BORNSTEIN, supra note 135, at 100.

${ }^{141}$ See, e.g., RAHMAN, supra note 133, at 118 (describing the various sources of funds for repayment of loans, and finding that only 3 percent of the time do borrowers borrow money from circle members in order to repay loans); Helen TOdD, WOMEN AT THE CENTER : GRAMEEN BANK BORROWERs AFTER ONE DeCADE 163167 (1996) (finding that circle members in her study area did at times help each other with repayment, but 
the system works shockingly well. ${ }^{142}$ Therein lies the mystery. Why does the Bank accept guarantors who do not have the capacity to repay the borrowers' loans? ${ }^{143}$ Some who have studied the Bank conclude that borrowers have the necessary information about each other's character, business judgment and chances of success to be able to successfully "screen" each other for loans. ${ }^{144}$ However, recent studies refute these conclusions, finding that borrowers may have accurate information about each other's character, but not about their chances of business success. ${ }^{145}$

I propose a different reason. In their small, close-knit communities, borrowers cannot default because doing so would risk extraordinary shame, social degradation and even ostracism. ${ }^{146}$ The guaranty required by the Bank is not realistically one of repayment by other solidarity circle

generally as a last resort, following resort to relatives, money lenders, and neighbors), and at 164 (quoting a borrower: "[Circle members] do not help me with repayment. They should, but they have no more [money] than me, so how can they?").

${ }^{142}$ The Grameen Bank's website states that its repayment rate is 97\%. Grameen Bank Homepage, Breaking the vicious cycle of poverty through microcredit, http://www.grameen-info.org/bank/bcycle.html. This is much higher than the average repayment rate of commercial banks in Bangladesh (and even of many US banks). Philip M. Nichols, Swapping Debt for Development: A Theoretical Application of Swaps to The Creation of Microenterprise Lending Institutions in Sub-Saharan Africa, 27 N.Y.U. J. INT'L L. \& PoL. 43, 67 (1994) (comparing the Grameen Bank's 98\% rate of repayment to the "commercial default rate in Bangladesh of seventy to ninety percent") (emphasis added).

${ }^{143}$ While the Bank's use of guarantors who cannot really act as guarantors is puzzling on its face, the high repayment rates by borrowers is at least partially explained by their desire for repeat loans from the Bank. Grameen Bank Homepage, Credit delivery system, http://grameen-info.org/bank/cds.html.

${ }^{144}$ See, e.g., Daryl J. Levinson, Collective Sanctions, 56 STAN. L. REV. 345, 396 (2003) ("[P]eer selection by borrowers mitigates the huge information asymmetries inherent in underdeveloped credit markets. While assessing the credit risks of Bangladeshi villagers would be prohibitively costly for a bank, the villagers themselves are intimately acquainted with each other's honesty, financial status, and work ethic."); Jaffer, supra note 102, at 202 ("Members of the group likely come from the same village, have known one another all their lives, and are intimately familiar with one another's financial situation."); Jacob Yaron, What Makes Rural Finance Institutions Successful?, 9 WORLD BANK RES. OBSERVER 49, 55 (1994) ("By leaving much of the screening process in the hands of people who know the borrower very well, Grameen Bank decreases one element of risk that faces most lenders: imperfect knowledge as to whether a borrower intends to default."); Joseph E. Stiglitz, Peer Monitoring and Credit Markets, 4 WORLD BANK ECON. Rev. 351, 353 (1990) ("[T]he Grameen Bank is able to exploit the local knowledge of the members of the group. It has devised an incentive structure whereby others within the village do the monitoring for it."); Solomon, supra note 133, at 198 ("Because group members assume mutual responsibility for each others' loans, the Bank can reduce staff time devoted to tracking loans and service more borrowers.").

${ }^{145}$ See, e.g., Chi-kan Richard Hung, From South to North: Comparative Study of Microcredit Programs in Developing Countries and US, in RePLiCATING MiCROFINANCE IN THE UNITED STATES 223, 248-251 (James H. Carr \& Zhong Yi Tong eds., 2002).

${ }^{146}$ RAHMAN, supra note 133, at 73-75 (describing the detailed and genderized requirements for maintaining honor in rural Bangladeshi society, with the heavier burden falling on women, and the extreme consequences that can flow from the shame of loan default), at 75 (quoting a borrower: "'When a woman fails to make her installments on time, she experiences humiliation through verbal aggression from peers and bank workers in the loan center. Such humiliation of women in a public place gives males in the household and in the lineage a bad reputation."'), and at 76 ("The safeguard of iijat (women's honor) by men in the society ... gives the lending institution an unwritten guarantee of getting back regular installments from its women borrowers."); BORNSTEIN, supra note 135, at 86 (quoting a borrower's husband as saying that "[i]f the bank lent money to men, ... they wouldn't get it back so conscientiously"); MUHAMMAD YUNUS, BANKER TO THE POOR: MicRo-LENDING AND THE BATTLE AGAINST WORLD POVERTY 63-64 (1999) (describing the extraordinary fear the average borrower experiences when she receives her first loan); Anne Marie Goetz \& Rina Sen Gupta, Who Takes the Credit? Gender, Power, and Control Over Loan Use in Rural Credit Programs in Bangladesh, 24 World DeVElopment 45, 61 (1996) (discussing the positional vulnerability of women in rural Bangladeshi society). 
members. It is that fellow members will shame the borrower into finding whatever means she can to repay her debts.

Thus, while most refer to the solidarity circle as making use of "peer pressure" to enforce loan terms, ${ }^{147}$ in fact the driving force behind that peer pressure is something more ethereal. ${ }^{148}$ When borrowers and bank managers consider prospective borrowers, they consider whether a person is honorable - and whether she is capable of losing her honor if she fails to repay her loan. ${ }^{149}$ When borrowers are interviewed about the consequences of loan default, they talk about their family's honor. ${ }^{150}$ Honor, then, is an asset that can be collateralized for use in a loan transaction. It can be leveraged for purposes of starting a small business. And shame is the risk that the poor incur for the privilege of participating in the market for credit.

\section{Collateralization through the mechanism of the solidarity circle}

The mechanism by which human worth is collateralized in this context is the solidarity circle. As is the case with credit reports, those who have studied peer lending laud the solidarity circle's ability to solve information asymmetries, ${ }^{151}$ without recognizing that the circle also serves as a powerful behavior modifier. And indeed, the solidarity circle does solve certain

\footnotetext{
${ }^{147}$ See, e.g., Grameen Bank Homepage, Credit delivery system, http://grameen-info.org/bank/cds.html.

${ }^{148}$ I acknowledge the existence of other factors that enhance the potency of peer pressure and the consequent likelihood of repayment in this setting. These include the methodology of lending to only one or two circle members at a time and the expectations of borrowers that they will be able to borrow from the bank repeatedly. See Grameen Bank Homepage, Credit delivery system, http://grameen-info.org/bank/cds.html. But, especially given the fact that default seems regularly to occur when an entire loan center determines that it has the right to default (see, e.g., TODD, supra note 141, at 153-157), my theory is that honor plays a large part in the peer pressure that is brought to bear in this context.

${ }^{149}$ See, e.g., BORNSTEIN, supra note 135, at 45 (discussing the use of peer pressure to counteract a borrower who was feeling "lazy" or who "began entertaining dishonorable thoughts"), and at 191 (discussing bank manager's comment that the poorest of the poor are not good borrowers because they are "floaters," "[o]ne day they're here, one day they're there"). See also Cao, supra note 102, at 882-883 (In the context of rotating credit associations, which are the basis for the peer lending methodology: "Norms of trust and reciprocity make cooperation possible and ensure that the borrower honors her obligation to repay by continuing to contribute regular sums into the pool until every member has had an opportunity to draw."), and at 884 ("[M]embers of an Ethiopian [rotating credit group] claim that 'it's easier to commit suicide' than to renege because loss of community standing is 'not like credit. It won't clear after seven years.' Because rotating credit associations are embedded in the community, default would result in expulsion from the association, resulting in 'shame on not just the individual, but that person's family. It likely would lead to difficulty in getting a job [in the community] or even getting a marriage partner."”).

${ }^{150}$ RAHMAN, supra note 133 , at 75.

${ }^{151}$ Levinson, supra note 144, at 396; Solomon, supra note 137, at 198 ("Treating the borrowers as a group throughout the loan process enables the Bank to reduce its analysis of each loan application, thereby decreasing the high transaction costs that ... discourage loans to small businesses. Because group members assume mutual responsibility for each others' loans, the Bank can reduce staff time devoted to tracking loans and service more borrowers."); Jaffer, supra note 102, at 201 ("Solidarity lending . . provides a screening method that is reliable, inexpensive, and that suffers no diseconomies of scale."); Jacob Yaron, supra note 144, at 55 ("By leaving much of the screening process in the hands of people who know the borrower very well, Grameen Bank decreases one element of risk that faces most lenders: imperfect knowledge as to whether a borrower intends to default."). See generally Joseph E. Stiglitz, supra note 144.
} 
information asymmetries. The personal relationships among members of the solidarity circle give them information about their peers that is helpful in determining whether they will be good credit risks. The Bank takes advantage of this knowledge by delegating the work of screening borrowers to members of the circle.

But in Bangladesh, too, the solidarity circle serves the more powerful purposes of constraining behavior and enabling liquidation. It does so by taking advantage of an elaborate, socially constructed understanding of honor, known as "iijat," which is shaped extensively by a sense of responsibility to the group rather than only (or at all) to the self. ${ }^{152}$ Islamic religious norms, village mores and gender roles all inform iijat. Iijat exists and must be protected and enhanced at the level of the individual homestead, the family's lineage, and the entire village. ${ }^{153}$ Responsibilities for protecting iijat are allocated along gender lines. ${ }^{154}$ In essence, by acting according to a set of standards representing ideal feminine behavior, a woman can maintain and enhance her family's status in the village. These standards include "shyness," "passivity," and "modesty." ${ }^{155}$ Moreover, norms contributing to iijat result in closer scrutiny of women's behavior than of men's. ${ }^{156}$ The consequences of loss of iijat are severe and, according to at least one source, irreversible. ${ }^{157}$ In contrast to their middle class or urban peers, for impoverished rural women who are typically unable to leave their village settings for other locales where they can pursue their livelihoods, the consequences are also inescapable. ${ }^{158}$

\footnotetext{
${ }^{152}$ Although a number of studies have discussed the link between the feminine role in rural Bangladesh and the Bank's decision to lend to women, Rahman (an anthropologist who lived in his study village for 11 months) is by far the most detailed about the nature and importance of iijat in Bangladeshi society. Thus, for purposes of understanding the anthropological features of iijat, I rely extensively on Rahman's work, which I believe to be methodologically quite rigorous. See id. at 22-38 (describing his methodology). I acknowledge, however, the possibility of bias in his study and in other studies of the Bank. For additional work on the concepts of honor and shame in rural Bangladeshi society, see, e.g., DAVID MANDELBAUM, WOMEN'S SECLUSION AND MEN'S HonOR: Sex Roles in North India, Bangladesh and PaKistan (1988); Naila Kabeer, Subordination and Struggle, 168 NEW LEFT REVIEW 95 (1988).

${ }^{153}$ RAHMAN, supra note 133, at 56-61, 68-69. Rahman found that the particular use of honor and shame in his study village was a result of village-level norms that were "culturally constructed." Id. at 74-75. Id. at 75

${ }^{154}$ Rahman found that women bear more responsibility overall for protecting and enhancing iijat than men.

${ }^{155} \mathrm{Id}$. Todd, who is not an anthropologist and in whose methodological rigor I have less faith, nonetheless describes a different but related concept of dignification known as "lokkhi": "Lokkhi refers to the wife who is both thrifty and hard working, whose management of the homestead is so competent that there is never want. Lucky is the man whose wife is lokkhi. He is respected...."). Id. at 98. Todd's description of Lokkhi in rural Bangladeshi society is similar to the function of iijat in that it places a particular genderized burden on the woman to enhance the family's honor.

${ }^{156}$ RAHMAN, supra note 133 , at 75.

${ }^{157} I d$.

${ }^{158}$ Goetz \& Sen Gupta, supra note 146, at 61 (women's positional vulnerability increases the pressure to repay); RAHMAN, supra note 133, at 74 (same). Rural Bangladeshi women regularly go to other countries to work, but they do not have the option to move there permanently. They also do not typically have the option to go back to their natal families. See e.g., ToDD, supra note 141, at 129-148.
} 
While the process by which credit reporting collateralized human worth may have been accidental, the Grameen Bank appears always to have recognized the solidarity circle's potential for collateralizing iiijat. The mechanism here is straightforward. The Bank uses a public system of accountability, which it describes as peer pressure, ${ }^{159}$ to threaten its borrowers with a diminution of their family's honor. In the Bank's own words, "the collective responsibility of the group serves as the collateral on the loan." 160 Certain features of the Bank's program heighten the peer pressure on borrowers. For example, the Bank requires borrowers to attend mandatory weekly meetings of all the borrowers in the village at which each borrower must provide a weekly payment on her loan. ${ }^{161}$ Thus, if a borrower misses or is short on a payment, she must admit this fact in front of many of the members of her village. The Bank compounds the humiliation experienced by delinquent borrowers by requiring the entire group to remain at the meeting, sometimes for hours, while the Bank questions delinquent borrowers about their tardy payments. ${ }^{162}$ The practice puts pressure on non-delinquent borrowers, who cannot return to their families and work until they are dismissed from the meeting, ${ }^{163}$ thereby implicating their honor as well. Thus, while Westerners, who typically are not aware of the cultural presence of iijat, have assumed that the solidarity circle functioned primarily as a screening device, its real power is as a means of harnessing iijat.

On its face, the feminine role imposed by iijat seems inconsistent with the "courage" and "empowerment" that the Bank claims it locates and develops in its female borrowers - and which it uses as partial justification for its decision to lend almost exclusively to women. ${ }^{164}$ Considered from the perspective of asset management, however, it is ideal. How better to increase the gravity of the risk of liquidation than to choose to lend to the member of society to whom the asset is most important? As a number of studies have found, if men fail to repay, the consequences are far less

\footnotetext{
${ }^{159}$ Grameen Bank Homepage, Credit delivery system, http://www.grameen-info.org/bank/cds.html (“[T]here is substantial group pressure to keep individual records clear."); Grameen Bank Homepage, Breaking the vicious cycle of poverty through microcredit, http://www.grameen-info.org/bank/bcycle.html (referring to the use of "powerful peer pressure").

${ }^{160}$ Grameen Bank Homepage, Credit delivery system, http://www.grameen-info.org/bank/cds.html.

${ }^{161}$ Mustafa A. Rahman et al., Grameen Bank in Employment Creation and Poverty Alleviation, 4 THE BANGLADESH PUB. ADMIN. J. 52, 56-57 (1990); RAHMAN, supra note 133, at 123.

${ }^{162}$ RAHMAN, supra note 133 , at 123.

${ }^{163}$ Id. at $123-24$.

${ }^{164}$ YUNUS, supra note 146, at 45-50 (describing his desire to empower the poor women whom he observed, which served as an impetus for founding the Grameen Bank), at 64 ("We want only courageous, ambitious pioneers in our micro-credit program."), and at 71 (describing his anger at the traditional banking system in which women constituted less than $1 \%$ of borrowers); BORNSTEIN, supra note 135, at 140 (describing Yunus's desire to empower impoverished women); RAHMAN, supra note 133, at 93 (describing the Bank's "public transcript" for seeking women borrowers as including the desire "to assist [women] to attain a greater socioeconomic empowerment in society").
} 
severe: the experience of shame is slight if present at all, and the more extreme consequences such as ostracism are rare. ${ }^{165}$ For women, on the other hand, the consequences of failure to pay can be permanent and severe. The Bank can literally count on repayment by its female borrowers.

Iijat's importance to rural Bangladeshi women is the key to its value as collateral. It is a powerful behavior modifier, because women's ongoing participation in the Grameen program requires stabilized feminine behavior. ${ }^{166}$ In that respect, of course, the Bank reinforces the feminine role in maintaining iijat. ${ }^{167}$ Moreover, iijat becomes dependent on material gain and loss. Thus, if a woman is honorable enough to be picked by her peers to join a circle, she must successfully complete a loan transaction to maintain her family's iijat. ${ }^{168}$ Her success as a market actor produces honor; her failure produces shame. Given the extraordinary saturation of the Grameen program in many rural villages, ${ }^{169}$ it seems fair to say that iijat has a new marketized meaning. Its maintenance is directly linked to a woman's ability to fulfill a specific feminine role.

Considered in this light, the efforts of Grameen borrowers to repay their loans at all costs are quite rational. And the costs can be high, including recycling debt by borrowing from money lenders at exorbitant rates, ${ }^{170}$ using savings and selling personal assets. ${ }^{171}$

\footnotetext{
${ }^{165}$ RAHMAN, supra note 133, at 73-74 (describing the Bank's decision to lend less to men (who were "arrogant" and argumentative) and more to women (who were "submissive" and obedient)), and at 75 (quoting a borrower: "'For a man, if he is locked inside the bank building for several days, it would mean almost nothing to other people in the village. But if this happens to a woman, then it will bring [a bad reputation] to her household, lineage, and village."'); TODD, supra note 141, at 159-160 ("[M]ainly in response to increasing repayment problems within male centers, the Grameen Bank Project began a shift towards recruiting mainly women members."); BORNSTEIN, supra note 135, at 86 (quoting a borrower's husband as saying that "[i]f the bank lent money to men, ... they wouldn't get it back so conscientiously").

${ }^{166}$ Many microlenders have adopted the peer lending model and have chosen to target women as borrowers. Rashmi Dyal-Chand, Reflection in a Distant Mirror: Why the West has Misperceived the Grameen Bank's Vision of Microcredit, 41 STAN. J. INT'L L. 217 (2005). This suggests that some of my claims about the use of honor are broadly applicable to microlending programs around the world. However, the particular use of iijat may be unique to the rural Bangladeshi context. Thus, it is important to recognize that, while human worth may serve as collateral in many of these programs, it may be differently defined and differently deployed even in different microlending contexts.

${ }^{167}$ In the Grameen context, it is actually the members of the solidarity circle, the borrowers, family members, and the local society who are making the value judgments integral to the construction of the feminine role (and, as I discuss, the importation of market behavior into that role), but the Bank harnesses those judgments for purposes of managing its lending program. Thus, it is effectively the Bank that marketizes dignity, by using it in the lending transaction.

${ }_{168}$ Moreover, Rahman has found that the vast majority of female borrowers seek loans from the Bank because they have been told by their family members to do so. Id. at 76 .

${ }^{169}$ Grameen Bank Homepage, Grameen Bank, http://grameen-info.org/bank/index.html ("As of July, 2004, [the Grameen Bank] has 3.7 million borrowers, 96 percent of whom are women. With 1267 branches, GB provides services in 46,000 villages, covering more than 68 percent of the total villages in Bangladesh.").

${ }^{170} \mathrm{Id}$. at $118,140-145$; ToDD, supra note 141 , at $164-165$.

${ }^{171}$ RAHMAN, supra note 133 , at 118 . It is also understandable why women strive to enhance their genderized roles. While other forces in society might very well motivate women to pursue a specific set of behaviors distinguishable from "male" behavior, the Bank's use of iijat appears to ensure it.
} 


\section{Iijat as collateral}

Though different in important respects from human worth as collateral in US consumer credit transactions, iijat as used by the Grameen Bank again exhibits a number of the important features of collateral.

\section{a. Quantifiable}

The quantification of iijat by the Grameen Bank is less straightforward a process than the quantification of human worth by means of credit reporting in the US. Nevertheless, several cultural phenomena help to quantify iijat in order to make it more useful to the Bank. For example, the combined vulnerability and immobility of women borrowers allows the Bank to track their behavior with ease. Additionally, because most borrowers borrow repeatedly from the Bank, the Bank is able to track the gravity with which a borrower treats her repayment obligations. By choosing borrowers who are more vulnerable to family and social pressures, or whose families have a higher status in the village, the Bank essentially quantifies human worth, rendering it capable of comparison among borrowers. The Bank's detailed statistics about individual borrowers suggest that it may be doing just that. $^{172}$

Many of these features are captured in the mechanism of the solidarity circle. For example, it is actually circle members, rather than the Bank itself, who make judgments about the relative status (honor) of a loan applicant and about her vulnerability to peer pressure. Moreover, the pressure from circle members reinforces a borrower's sense of all that she has to lose if she fails to repay her loan on time.

\section{b. Capable of liquidation}

The Grameen Bank can liquidate iijat much like US banks can liquidate human worth, though here too the details are quite different. As I have described, Grameen borrowing is a very public process. Thus, when a borrower fails to make a payment, she is humiliated before many of the people she knows. Women's particular obligation to maintain iijat ensures that they understand the dangers of loss of iijat. However, the Bank does not leave much to chance. It ensures borrower awareness of the implications of a failure to pay by, for example, talking with the borrower's

\footnotetext{
${ }^{172}$ BORNSTEIN, supra note 135 , at 220-223.
} 
relatives about payment delinquencies. ${ }^{173}$

In addition, as Grameen loans become a primary source of wealth accumulation, a decision by the Bank not to lend again to a delinquent borrower greatly affects her ability to improve her economic position. In this respect, the marketization of iijat contributes to the ease by which it can be liquidated by the Bank.

\section{c. Capable of appreciation}

As I have described, a woman's aptitude in fulfilling an idealized feminine role, as defined by iijat, increases her family's honor. It also makes her a more desirable candidate for a loan. In this way, women can cause their collateral to appreciate in value. Interestingly, behavior that causes asset appreciation contrasts with the empowerment that Westerners perceive the Bank as encouraging in its women borrowers. The fact that a very large percentage of borrowers lose control of loan funds to male family members suggests that the Bank recoups its funds not from successful microenterprises, ${ }^{174}$ but rather from the threat to iijat perceived by borrowers.

\section{d. Meaningful to borrower}

Obviously, the centrality of iijat to rural Bangladeshi life makes it an extraordinarily important asset to collateralize. As is the case for credit card borrowers in the US, it is difficult to imagine a more potent form of collateral.

\section{e. Easy to monitor}

By its nature, iijat is a public system, dependent on the perception of others for its potency. Thus, the Grameen Bank is able to rely on the eyes and ears of circle members to determine the proficiency with which a borrower is maintaining iijat. By delegating this function to circle members, the Bank reduces its own costs of lending.

\section{f. Transferable}

\footnotetext{
${ }^{173}$ RAHMAN, supra note 133, at 81-83 ("When this peer pressure failed to convince the irregular borrower, then the institutional pressure (bank workers and bank officers) and wider social pressure (village ... leaders) was imposed on the members of the borrower's household."). See also BORNSTEIN, supra note 135, at 85.

${ }^{174}$ RAHMAN, supra note 133, at 109-113; TODD, supra note 141, at 83-90; Goetz \& Sen Gupta, supra note 146, at 61; CounTs, supra note 135, at 81. See also Taylor, supra note 134, at 327 (describing loss of loan fund control as a problem in the microcredit industry overseas); DAVID HulME \& PAUl MosLEy, FINANCE AGAINST POVERTY, VOLUME 1, 129 (1996) (same).
} 
It does not appear that the Grameen Bank has found a way to repossess its borrower's human worth. Thus, as is the case in the US, an important distinction between human worth as collateral and other forms of collateral is that the former cannot serve as a means of collecting payment from delinquent borrowers. Nonetheless, as we have seen, the Bank receives many of the benefits from collateralizing iijat that lenders typically receive from security.

\section{Law's irrelevance}

In Bangladesh, the law simply is irrelevant to the Grameen Bank's program. In contrast to US credit card lenders, the Bank chooses not to use legal enforcement, relying exclusively on its system of peer pressure. Indeed, its founder touts the program's reliance on trust rather than on "legal instruments," "meaningless paper contracts," or courts. ${ }^{175}$ Thus, although the Bank implicitly capitalizes on its borrowers' sense of self worth, the law does not appear relevant to this process. As in the US, it appears to be the Bank itself that developed this important innovation in lending practices.

\section{Universal, Hierarchical, Personal, Communitarian?}

The remainder of this article explores the nature and implications of the new collateralization described above. Until now, I have used human worth, dignity, honor, pride, and personhood interchangeably. However, lenders and laws probably are warranted in treating pride of status differently from a sense of human worth, and group honor differently from individual personhood. It is quite likely that more is at stake in some instances than in others. Moreover, it is not readily apparent whether middle class American borrowers are risking the same thing as impoverished Bangladeshis.

In this section, I begin the process of clarifying the use of human worth as collateral. To a large extent, this is an ends-driven process, both limited and biased by the examples I have used to support my hypothesis. I attempt here only to identify a process of social evolution in two lending schemes. Moreover, my focus necessarily is more on Western notions of human worth, and on the US example, because the details of Bangladeshi society, and its understanding of human worth, are far more opaque to me.

Western philosophical discussions often refer to human worth as

${ }^{175}$ YunUS, supra note 146, at 70. 
dignity. Dignity has been described as that which distinguishes human beings from other animals:

The dignity and pre-eminence of human nature by which it excels over other living beings required that human acts were judged according to a fixed norm, because there cannot be conceived of any order, splendor or beauty beyond this dignity. ${ }^{176}$

Beyond this basic definition, however, dignity always has been a multifaceted and paradoxical concept. A primary paradox inherent in Western notions of dignity, for example, is its simultaneous universality (in that it is an attribute of all human beings) and utility as a status-enhancer (in that it distinguishes among human beings). Four images of dignity resonate particularly well in the lending contexts described here.

\section{A. Universal}

Since its emergence in the West, dignity has been defined as universal in nature. ${ }^{177}$ As expressed by Immanuel Kant: "a person...is not to be valued merely as a means to the ends of others or even to his own ends, but as an end in himself, that is, he possesses a dignity...by which he exacts respect for himself from all other rational beings in the world."178 According to this image of dignity, it is immutable and thus incapable of being lost. ${ }^{179}$ It is therefore a source of equality among human beings. ${ }^{180}$

\footnotetext{
${ }^{176}$ Samuel Pufendorf, De iure naturae et gentium, in GESAMMELTE WERKE, vol. 4 (F. Bohling, ed., 1998).

${ }^{177}$ Cicero, for example, described human dignity as inherent "in human nature." Hubert Cancik, 'Dignity of Man' and 'Persona" in Stoic Anthropology: Some Remarks on Cicero, De Officiis I 105-107, in THE CONCEPT OF HUMAN DigNITY IN HUMAN RIGHTS DiscourSE 19 (David Kretzmer \& Eckart Klein eds., 2002).

${ }^{178}$ IMMANUEL KANT, THE METAPHYSICS OF MORAlS 434-435 (Mary Gregor trans., 1991) (1797).

${ }^{179}$ See Jean-Jacques Rousseau, Discourse on the Origin and Foundations of Inequality Among Men, in THE Discourses AND OtHeR EARLy Political Writings 111, 166 (Victor Gourevitch ed. \& trans., 1997) (1766); Jean-Jacques Rousseau, Of the Social Contract, in THE Social CONTRACT AND OTHER LATER POLITICAL Writings 39 (Victor Gourevitch ed. \& trans., 1997) (1762); Michael J. Meyer, Introduction to THE CONSTITUTION OF Rights: Human Dignity and American Values 1, 4-7 (Michael J. Meyer \& William A. Parent eds., 1992) (discussing Paine's emphasis on the "natural dignity of man" as counter to historical views of dignity as rank). The link between dignity and the intrinsic moral value, and the resulting imperative, of human beings also has roots in many Western religious traditions. See Yehoshua Arieli, On the Necessary and Sufficient Conditions for the Emergence of the Doctrine of the Dignity of Man and his Rights, in THE CONCEPT OF HUMAN Dignity IN Human Rights Discourse 1, 10 (D. Kretzmer \& E. Klein eds., 2002) (describing the Biblical sources of the "feeling of awe, of pride and humility in the relationship between man and God which lies at the basis of the concept of the inherent dignity of man"); Mary Ann Glendon, Foundations of Human Rights: The Unfinished Business, 44 AM. J. JURIS. 1, 13 (1999) ("Most [religious] believers . . . would say that dignity is grounded in the fact that human beings are made in the image and likeness of God."). See also ANITA GANERI \& Marcus Braybrooke, Religions Explained (1997); Louis P. Pojman, On Equal Human Worth: A CRITIQUe OF CONTEMPORARY EgalitARIANISM, IN EQUAlity 282 (Louis P. Pojman \& Robert Westmoreland, eds., 1997); EMIL BRUNNER, THE Divine IMPERATIVE (1947). There are similar examples of the association between dignity and the human moral condition in non-Western religions. See generally GANERI \& BRAYBROOKE.

${ }^{180}$ See, Ronald DwORKIN, TAKING Rights SERIOUSLY 198 (1977) ("Anyone who professes to take rights seriously, and who praises our Government for respecting them, must have some sense of what that point is. He
} 
The universalist image of dignity has been enormously important to Western legal traditions. It was central to the development of the United Nations Charter ${ }^{181}$ and the Universal Declaration of Human Rights. ${ }^{182}$ It has also been important in Supreme Court jurisprudence interpreting the US Constitution. ${ }^{183}$ In contemporary legal debates, dignity informs arguments that human beings cannot be assigned a market value. ${ }^{184}$ For example, dignity is used in bioethics discussions to argue against the patentability of human beings (or their genes or other parts). ${ }^{185}$

Universalist dignity also appears to have a place in credit card lending and microlending, though as we shall see, so does the more hierarchical version of dignity. In contrast to owning a house or a refrigerator, presumably everyone has a sense of honor that can serve as collateral for a loan. ${ }^{186}$ In this respect, then, human worth as collateral has an equitable

must accept, at the minimum, one or both of two important ideas. The first is the vague but powerful idea of human dignity. This idea, associated with Kant, but defended by philosophers of different schools, supposes that there are ways of treating a man that are inconsistent with recognizing him as a full member of the human community, and holds that such treatment is profoundly unjust."); Jeffrie G. Murphy, Moral Death: A Kantian Essay on Psychopathy, 82 ETHICS 291 (1972) ("[I]n claiming a right . . . [one] speaks legitimately only insofar as he is prepared to recognize and respect his obligation to defer to others' rights in similar kinds of circumstances."); Thomas Nagel, The Possibility OF Altruism 107 (1970) ("[O]ne's basic practical principles must be universal."). This view has also been attributed to John Rawls. See JOHN RAWLS, A THEORY OF JUSTICE 151 (1971) (concluding that individuals who are unaware of their social status, natural abilities and other external factors will "establish[] equal liberty for all, including equality of opportunity, as well as an equal distribution of income and wealth.").

${ }^{181}$ The Preamble to the United Nations Charter states: "We the Peoples of the United Nations Determined ... to reaffirm faith in fundamental human rights, in the dignity and worth of the human person ...." U.N. Charter preamble.

${ }^{182}$ The Preamble to the 1948 Universal Declaration of Human Rights begins: "Whereas recognition of the inherent dignity and of the equal and inalienable rights of all members of the human family is the foundation of freedom, justice and peace in the world." Universal Declaration of Human Rights pmbl., G.A. Res. 217, U.N. GAOR. 3d Sess., at 71, U.N. Doc. A/810 (1948). Article I of that document states: "All human beings are born free and equal in dignity and rights." Id. art. I.

${ }^{183}$ See Judith Resnik \& Julie Chi-hye Suk, Adding Insult to Injury: Questioning the Role of Dignity in Conceptions of Sovereignty, 55 STAN. L. REV. 1921 (2003).

${ }^{184}$ See MARgaret JANE RAdin, CONTESTED COMMODITIES (1996). For a helpful description of the debates concerning commodification of human beings, see Note, The Price of Everything, the Value of Nothing: Reframing the Commodification Debate 117 HARV. L. REV. 689 (2003).

185 See, e.g., David BeYleveld \& Roger Brownsword, Human Dignity in Bioethics AND BIOLAw (2001); David B. Resnik, DNA Patents and Human Dignity, 29 J.L. MEDICINE \& ETHICS 152, $155-156$ (2001) ("The principle of humanity also implies that moral worth is held equally, as it does not make sense to say that someone has greater moral value than someone else does. . . . Thus, if human beings have intrinsic value, then they have a value or worth that cannot be captured in markets terms; their worth cannot be measured in terms of a price.").

Similar arguments have been made concerning sale of human organs. See, e.g., Leon R. Kass, Organs for Sale? Propriety, Property, and the Price of Progress, in Politics AND THE Human Body: Assault ON DigniTy 153 (Jean Bethke Elshtain \& J. Timothy Cloyd eds., 1995); Margaret Jane Radin, Market-Inalienability, 100 HARV. L. REV. 1849 (1987).

${ }^{186}$ In the case of the Grameen Bank, for example, women who were foreclosed from market participation because they had nothing were allowed to leverage dignity as collateral. See supra notes 148-151 and accompanying text. See also Taylor, supra note 134, at 319 (discussing microcredit programs' targeting of the "poorest of the poor" and women because "as a group, they often face social barriers to entry into the formal economy and turn to the informal sector to provide for themselves and their families"). 
quality. It can be argued that by quantifying and collateralizing human worth, banks in the US and Bangladesh have leveled the playing field of the market; they have created opportunities for market participation where such opportunities might previously not have existed. ${ }^{187}$ The egalitarian aspect of human worth as collateral may also be linked to some of the positive externalities for which commentators have praised these lending programs. These can include a Weberian valorization of wealth resulting from watching one's peers behave in a disciplined manner, ${ }^{188}$ the creation of role models in economically marginalized communities, ${ }^{189}$ and, most ambitiously, the idealization and replication of the middle class. ${ }^{190}$

Thus, it seems possible that modern-day lenders are successfully capturing a universalist form of dignity that goes to the very core of humanness. Indeed, universalist dignity as collateral may partly explain the seemingly irrational decision by credit card lenders to lend to financially marginalized consumers. To the extent the credit market is successfully harnessing universal dignity, the advantages for both lenders and borrowers are quite significant. The economic benefits described above could allow people along a far broader socio-economic spectrum to accumulate wealth via credit. Perhaps credit will never be universal, but it might be more broadly distributive. The democratic nature of the credit card industry's current marketing practices might also help to reduce racial and other discrimination in lending practices. It will be interesting to observe, in the next decade, whether credit card lenders overtake predatory, pay day and other marginal lenders in providing credit to populations whom mainstream banking services currently exclude. Obviously, such benefits will only evolve if appropriate regulations limit predatory tendencies on the part of credit card lenders. ${ }^{191}$

187 An analogy might be found in the debates about whether to deregulate (or reduce regulation of) adoptions. See, e.g., Elisabeth M. Landes \& Richard A. Posner, The Economics of the Baby Shortage, 7 J. LEGAL STUD. 323 (1978); Ronald A. Cass, Coping With Life, Law, and Markets: A Comment on Posner and the Lawand-Economics Debate, 67 B.U. L. REv. 73 (1987); Richard A. Posner, The Regulation of the Market in Adoptions, 67 B.U. L. REv. 59 (1987); George William Myers, Jr., Independent Adoptions: Is the Black and White Beginning to Appear in the Controversy Over Gray-Market Adoptions?, 18 DUQ. L. REV. 629 (1980).

${ }^{188}$ See SIMON, supra note 102 , at 56-57.

${ }^{189} \mathrm{Id}$.

${ }^{190}$ See David Dante Troutt, Ghettoes Made Easy: The Metamarket/Antimarket Dichotomy and The Legal Challenges of Inner-City Economic Development, 35 HARV. C.R.-C.L. L. REV., 427, 427-434 (2000) (discussing the connection between "wealth formation and consumer infrastructures" and "a relationship with government typically characterized by political participation and accommodation"); Anthony D. Taibi, Banking, Finance, And Community Economic Empowerment: Structural Economic Theory, Procedural Civil Rights, and Substantive Racial Justice, 107 HARV. L. REV. 1463, 1521-1522 (1994) ("Developing credit in low- and moderate-income communities is vital to our nation's economic prospects ... [Community development financial institutions'] lending programs encourage entrepreneurship, self-sufficiency, and creative problem solving —essential qualities for national and community economic prosperity, and for breaking the cycles of poverty and welfare dependency.").

${ }^{191}$ Elsewhere, I discuss the problem of predatory credit card lending. Dyal-Chand, From Status to Contract, supra note 119, Part II.B. 


\section{B. Hierarchical}

But historically, dignity has always had another face, one that directly contradicts its universal quality. According to this image, dignity is available only to those who deserve it. It is a status enhancer. Thus, for example, in both Ancient Rome ${ }^{192}$ and eighteenth century Europe, ${ }^{193}$ the aristocracy was dignified and virtuous, and those of lower rank were not. Recent scholarship has proposed that, although this hierarchical image of dignity has been de-emphasized in post-war political and philosophical thinking, it nonetheless underlies popular understandings of dignity in such areas as privacy rights ${ }^{194}$ and laws on sex and sexuality. ${ }^{195}$ As James Whitman points out, for example, although contemporary European privacy laws protect all members of society, their roots (and their underlying logic and primary purpose) are in the protection of high-status people from public insult or exposure. ${ }^{196}$

In contrast (perhaps) to its more historical or marginal importance in such areas as privacy laws, hierarchical dignity plays a much more central role in contemporary lending schemes. In the first place, human worth cannot serve as collateral if it is immutable. The possibility of liquidation presupposes a hierarchical form of human worth whereby borrowers who do not repay their debts are publicly shamed. This means both that human worth must be capable of reduction and also that those who use human worth as collateral must care about their social status. To a lender, human worth is not very meaningful collateral when offered by a borrower who cares little for her reputation. Note that this does not presume that only the rich or those of high social rank can collateralize their human worth; as both my examples suggest, the poor also care about their honor. But we ought to be able to imagine some prototypes in each society for whom human worth is less meaningful: the prostitute in Bangladesh, or the homeless person living on a street corner in the US. ${ }^{197}$

In addition to these logistical considerations, human worth as collateral is a status enhancer because it enables consumers to acquire status-

\footnotetext{
${ }^{192}$ Cancik, supra note 177 at 20.

${ }^{193}$ Whitman, supra note 94 , at 1165-66.

${ }^{194} I d$.

${ }^{195}$ Libby Adler, Dignity and Degradation: Transnational Lessons from the Constitutional Protections of Sex, [forthcoming].

${ }^{196}$ Whitman, supra note 94 , at $1169-70$.

${ }^{197}$ Obviously, there are excellent counterarguments that prostitutes and homeless people have dignity too, but it seems quite possible that non-mainstream definitions of dignity, and means of dignification, exist among these populations.
} 
enhancing goods and services on credit. In the US, as I have argued here and elsewhere, ${ }^{198}$ credit is used as a means to attain middle class status by means of material symbols of wealth. In Bangladesh, Grameen borrowers use their loans overtly to establish small businesses and covertly to buy land, pay dowries and otherwise raise their social status. ${ }^{199}$ Additionally, in both the US and Bangladesh, creditworthiness is itself a source of pride. ${ }^{200}$ In this respect, the use of human worth as collateral shapes human worth. Thus, at the same time that universalist dignity as collateral allows greater access to credit, hierarchical dignity as collateral contributes to economic and social stratification.

\section{Personhood}

A third image of human worth that resonates with its use as collateral is that of personhood as dependent upon control of property, a connection explored in detail by Professor Radin. ${ }^{201}$ Building on Hegel's conceptualization that "[a] person becomes a real self only by engaging in a property relationship with something external," ${ }^{202}$ Radin concludes that there are certain things, such as one's physical home or a wedding ring, that help constitute a person ${ }^{203}$ and that these things justify greater property entitlements. ${ }^{204}$ Thus, the legal right of privacy in one's home is not, Radin argues, just about the right of liberty. It is also a recognition that the home embodies personhood. ${ }^{205}$

Radin's analysis is relevant here in at least two respects. First, the collateralization of human worth works a curious inversion on the Radin/Hegel formulation. Using Hegel's description, the use of human worth in the consumer credit context could be described as follows: a person becomes a real self by engaging in a property relationship with herself. In this new formulation, the thing propertized is not even as "external" as one's organs, which are among the types of "personal" property that Radin describes as potentially self constituting. ${ }^{206}$ It is one's personhood. Perhaps this is a refutation of, or at least a limitation to, Radin's analysis. Perhaps it is a modern extension.

\footnotetext{
${ }^{198}$ See supra notes 84-102 and accompanying text. See also Dyal-Chand, From Status to Contract, supra note 119, Part III.B.

${ }^{199}$ RAHMAN, supra note 133, at 106-107; TODD, supra note 141, at 24 .

${ }^{200}$ See supra notes 103, 168-169 and accompanying text.

${ }^{201}$ Margaret Jane Radin, Property and Personhood, supra note 25.

${ }^{202}$ Id. at $972-973$.

${ }^{203}$ Id. at $959-961,986-988$.

${ }^{204}$ Id. at Part V.

${ }^{205} I d$. at $991-992$.

${ }^{206} I d$. at 966.
} 
The Radin/Hegel formulation also can be used aptly to describe the importance of credit in contemporary society. Given the importance of credit as a means of wealth formation, credit could be said to be that external thing upon which modern consumers can act in order to become "real selves." In other words, credit produces personhood. Again, this conceptualization propertizes personhood, emphasizing its utilitarian and hierarchical nature. It also gives credit a role that is simultaneously more central and more intimate than the law currently recognizes.

\section{Communitarian}

Although Western conceptualizations of dignity focus largely on the dignity and the attendant rights of the individual, some non-Western understandings define dignity as an attribute of a community. The following formulation of a common African belief suggests a group-based sense of dignity that is in marked contrast with Kant's idea of a person as an "end in himself," exacting respect "from all other rational beings" "207: "I am because we are, and because we are therefore I am." ${ }^{208}$ Often associated with group-based understandings of self worth is a sense of duty to the group as well as, or some times instead of, a sense of entitlement vis-à-vis the group. ${ }^{209}$ This formulation has practical consequences. In the debate about human rights norms, for example, a communitarian notion of dignity might lead to laws seeking to develop, maintain and protect any given person's "physical and psychic security of group membership." 210 Thus, as Makau Wa Mutua discusses, the state might focus on the rights of the family in addition to or instead of the rights of the individual. ${ }^{211}$

Those who have studied communitarian dignity debate whether this image of dignity masks cultural relativism and the elitist enforcement of social stratification. $^{212}$ However, communitarian dignity is not necessarily either egalitarian or hierarchical. At the most basic level, it is merely an acknowledgment that a person's sense of self is informed by (or even embodied in) her belonging to one or more groups.

Communitarian dignity clearly plays a role in the Grameen Bank's use

\footnotetext{
${ }^{207}$ KANT, supra note 178 , at 434-435.

208 JOHn MBITI, AFRICAN RELIGIONS AND PHILOSOPHy 141 (1970).

209 Makau Wa Mutua, The Banjul Charter and the African Cultural Fingerprint: An Evaluation of the Language of Duties, 35 VA. J. INT'L L. 339, 359-64 (1995).

${ }^{210}$ Rhoda Howard, Group Versus Individual Identity in the African Debate on Human Rights, in Human Rights in Africa: Cross-Cultural Perspectives 159, 166 (Abdullahi A. An-Na'im \& Francis M. Deng eds., 1990).

${ }^{211}$ Mutua, supra note 209, at 371 (discussing the African Charter).

${ }^{212}$ See, e.g., Id., Howard, supra note 210; Radhika Coomaraswamy, Identity Within: Cultural Relativism, Minority Rights and the Empowerment of Women, 34 GEO. WASH. INT'L L. REV. 483 (2002).
} 
of the solidarity circle to modify the behavior of its women borrowers. Iijat, the version of human worth that serves as collateral in this context, defines and is defined by membership in a group, or more specifically in a number of groups: the nuclear family, the extended family, and the village. Iijat also defines gender roles. By harnessing iijat, the Bank contributes to its preservation. Those who do not care about their family's or village's honor are not going to be desirable candidates for a Grameen loan.

It is difficult to know whether the Bank's use of iijat as collateral also changes iijat. The Grameen context could exemplify the fact that communitarian dignity need not be hierarchical. Studies of women borrowers in the Grameen system have found women who perform their roles as equal partners with the male members of their family and who are valued equally for their contributions. ${ }^{213}$ Unfortunately, however, these examples appear to be more rare than those of women burdened by the hierarchical version of iijat. ${ }^{214}$ At the very least, it seems that the collateralization of iijat changes iijat into something more marketized than its original meaning.

While communitarian dignity has an important role in Bangladesh, it is not entirely absent from the US context. Importantly, the status-enhancing use of dignity by credit card lenders works in part because people try to associate themselves with the middle class or with a particular neighborhood. These attempts at group membership help define people's self worth. However, this type of communitarianism is very different from that embodied in iijat. At bottom, the use of group-based notions of dignity appears to be more different than similar between the two contexts.

\section{E. Differences and Similarities}

What we see in these two examples, then, are all four aspects of dignity. It is likely that the Bangladeshi example emphasizes communitarian values more than the US example, and that the US example emphasizes more individualistic notions of dignity. Thus, while individuals in both contexts feel profound shame over bad credit, the reasons might be different. In the US, the shame might result from loss of status vis-à-vis others, whereas in Bangladesh it might result from a sense of failing one's group. ${ }^{215}$ It is also

\footnotetext{
${ }^{213}$ See, e.g., ToDD, supra note 141, at 29-54. See also Mohammad A. Auwal \& Arvind Singhal, The Diffusion of Grameen Bank in Bangladesh: Lessons Learned about Alleviating Rural Poverty, 14 KNOWLEDGE: Creation, Diffusion, Utilization 7 (1992) 21; Sidney Ruth Schuler, et al., Credit Programs, Patriarchy and Men's Violence Against Women in Rural Bangladesh, 43 Soc. ScI. MED. 1729 (1996).

${ }^{214}$ See, e.g., RAHMAN, supra note 133, at 73-74; Goetz \& Sen Gupta, supra note 146, at 61.

${ }^{215}$ Relatedly, the egalitarian nature of dignity might be Kantian in origins in the US and grounded in Islamic and communitarian norms in Bangladesh.
} 
possible that the Hegelian notion of property for personhood resonates more deeply in the US.

Although an in-depth cross-cultural analysis is beyond the scope of this article, the details of what is being collateralized and the ways in which collateralization occurs quite likely differ from context to context. For those who, like me, seek to understand the effect of rule of law initiatives, these differences are important because they can, among other things, help explain the extent to which target populations embrace cross-cultural development programs. For example, we might find that the positive externalities resulting from the collateralization of universalist dignity in the US do not occur in Bangladesh because Bangladeshi women value wealth using a communitarian lens rather than an individualistic one.

But we also see a startlingly similar use of human worth in two completely different programs, with different social and cultural histories and norms. In both the credit card lending and peer lending contexts, consumers are using a hierarchical version of dignity to secure credit. Moreover, in both places, the credit obtained enables wealth accumulation in the form of material assets and income generation, and credit itself functions as a form of wealth. Also, in both contexts, credit informs human worth by being a source of pride. Finally, in both contexts, the collateralization of human worth appears to accomplish broader distribution of credit and wealth. The process is a cycle in which human worth as collateral reinforces hierarchical dignity, which produces a broader distribution of credit, and reinforces the marketization of human worth.

\section{THE RULE OF THE MARKET?}

There are many lessons to be learned from the uses of human worth by contemporary lenders. At the pragmatic level, it is important to gain a more empirical understanding of what this new collateralization means to lenders and borrowers. What opportunities and risks do they identify? How do they value dignity as collateral? Do the benefits accruing from broader distribution of credit by means of universalist dignity outweigh the disadvantages of social stratification by means of hierarchical dignity? Moreover, what legal regulation is required in this new context? In addition to these pragmatic questions, there are important sociological considerations. How does the collateralization of human worth change social and cultural understandings of human worth? What additional images of dignity resonate in this context? There are also important economic concerns. Is human worth the new home? Will it produce the 
same benefits that homeownership has produced in the US? Can it be used to solve market failures in the inner city? Or is it an inherently limited asset?

But my purpose in discussing these two examples here is to explore a hypothesis about globalization, markets, human worth and the rule of law. The piece of this phenomenon about which I want to comment is the fact of convergence, how it happened and what it can teach us. Again, many more details are necessary to substantiate this or any other guess about the cause, but several aspects of the convergence are striking.

First, certain characteristics of human worth consistently materialize when it serves as collateral. In both contexts, it is hierarchical, utilitarian and broadly distributive. Thus, it appears that human worth is not just collateralized in the two settings, but also that it is in a sense consolidated.

It does not appear, however, that such a consolidating force found its basis in legal rules exported from the West to the East. This is the second striking aspect of the convergence. As I have argued, in both contexts, the law has failed to recognize this new use of human worth. While noteworthy for many reasons, for my purposes this failure is important because it has occurred against a backdrop of two decades in which the West has written commercial legal codes for the East. ${ }^{216}$ Property rules, ${ }^{217}$ banking rules, ${ }^{218}$ and rules about secured and unsecured lending ${ }^{219}$ all have found their way to the East from the desks of Western lawyers. But legal scholars continue to wonder whether these rules can successfully be exported. Will they

\footnotetext{
${ }^{216}$ Thomas Carothers, The Rule of Law Revival, 77 FOREIGN AFFAIRS 95, 96 (1998) (claiming that Western nations and private donors have poured hundreds of millions of dollars into legal reform in the last twenty years); Wade Channell, Lessons Not Learned about Legal Reform, in PROMOTING THE RULE OF LAW ABROAD: IN SEARCH OF KNOWLEDGE 137 (Thomas Carothers ed., 2006) (discussing the extensive Western reform of commercial law since the fall of the Soviet Union); J. Peter Byrne \& Philip G. Schrag, Law Reform in Estonia: The Role of Georgetown University Law Center, 25 LAW \& POL'Y INT'L BUS. 449, 456-60 (1994) (describing a 1992 Georgetown University delegation to Estonia (with U.S. government funding), featuring six law students who helped draft Estonian anti-monopoly statutes and complete civil and commercial codes); John C. Reitz, Export of the Rule of Law, 13 TRANSNAT'L L. \& CONTEMP. ProbS. 429, 431, 452, 479 (2003) (discussing the Georgetown Estonian project, the European Bank of Regional Development's export of portions of the UCC, and the legal export and reform activities of the Central and East European Law Initiative of the ABA); David M. Trubek, The "Rule of Law" in Development Assistance: Past, Present, and Future, in The New LAW AND ECONOMic DeVelopment: A Critical ApPRAisal (David M. Trubek \& Alvaro Santos, eds., forthcoming, 2006) (stating that the World Bank alone spent \$2.9 billion dollars on 330 law reform projects between 1990 and 2003).

${ }^{217}$ Since the late 1980 's, the World Bank has been involved in reforming the property rules and frameworks of many developing countries. Baharoglu, Deniz, World Bank Experience in Land Management \& The Debate on Tenure Security, (July 2002) (unpublished draft report, available at http://www.worldbank.org/urban/publicat/land_final.pdf). See also THE ECONOMIST, Mar. 31, 2001 at 20 (advocating the continued Westernization of the Third World's property laws).

${ }^{218}$ See, e.g., Economics Focus: Of Angels and Banking, THE ECONOMIST, Apr. 1, 2006 at 32 (describing attempts to standardize the world's banking regulations in the Western model).

${ }^{219}$ Emmanuel Maurice, Nurturing Small Business, Lit Online: A Supplement to Law in Transition, (2003) (available at http://www.ebrd.com/pubs/legal/OLO3a.pdf).
} 
succeed in making transactions more efficient? ${ }^{220}$ Will they improve the wealth of the nations that use them, or at least make these nations more effective trading partners with Western nations? ${ }^{221}$ Is the rule of law, in other words, meaningful in accomplishing economic development?

I think the convergence of human worth as collateral in these two lending schemes serves as a counter-example to the claimed centrality of the rule of law. In the US, a system where secured lending is wellestablished, lenders are choosing to lend outside of the formal parameters of both Article 9 and the laws on unsecured lending. Formally, they are exercising the rights of unsecured creditors. But informally, they are taking advantage of a much more powerful force by collateralizing human worth. One indication of this informal enforcement is the extensive and effective use of bill collectors. $^{222}$ In Bangladesh, the Grameen Bank uses no court enforcement at all, relying exclusively on peer pressure to enforce repayment. $^{223}$ In these examples, the lenders are structuring an extremely effective market for credit without the aid of laws that should be directly applicable. $^{224}$

I suspect instead that the consolidating force at work in these two contexts is the credit market and that it is globalizing both lending practices and notions of human worth. The third noteworthy piece of the convergence, then, is that the lenders' quest to solve information asymmetries in both contexts produced a much more effective means of protecting the lenders than the information itself produced. In the US, credit reports are an extremely concise, accurate, and low-cost means of capturing information about borrowers, but their real power lies in the threat

\footnotetext{
${ }^{220}$ See supra note 40 and accompanying text.

${ }^{221}$ See Richard A. Posner, Creating a Legal Framework for Economic Development, 13 THE WoRLd BANK RES. OBSERVER 1, 6, 9 (1998) (arguing that the adoption of portions of the UCC by poor countries to govern transactions would improve economic development). See generally Carothers, supra note 216, at 104 (arguing that the effects of the rule of law reform efforts of the past twenty years are positive, but modest); Randall Peerenboom, Law and Development of Constitutional Democracy in China: Problem or Paradigm?, 19 Colum. J. ASIAN L. 185, 192 (2005) (arguing that the rule of law is necessary, but not sufficient, for economic development); O. Lee Reed, Law, the Rule of Law, and Property: A Foundation for the Private Market and Business Study, 38 AM. Bus. L. J. 441 (2001) (arguing that the rule of law, in the Western model, is essential for economic development); Rohit Sachdev, Comparing the Legal Foundations of Foreign Direct Investment in India and China: Law and the Rule of Law in the Indian Foreign Direct Investment Context, 2006 COLUM. BUS. L. REV. 167, 169 (2006) (arguing that China's huge advantage in foreign direct investment over India is a result of China's relative lack of rule of law, giving it more flexibility in encouraging investment).

${ }^{222}$ See supra note 128-129 and accompanying text.

${ }^{223}$ See supra note 175 and accompanying text.

${ }^{224}$ This observation about the irrelevance of the rule of law is not new. Karl Llewellyn's 1931 discussion of whether contract law is necessary clearly addresses similar concerns. Karl Llewellyn, What Price Contract - An Essay in Perspective, 40 YALE L. J. 704, 718-722 (1931). In the field of secured transactions, Professor Mann's work on intellectual property as collateral addresses some of the same issues. Mann, Software Financing, supra note 9. The point is worth making again, however, given resurgence of rule-of-law rhetoric in economic development discussions.
} 
they pose to borrowers' sense of self worth. In Bangladesh, the solidarity circle provides information to the Grameen Bank about individual borrowers' creditworthiness, but the real power of the circle lies in its ability to harness iijat. In other words, lenders in two very different contexts shared quite similar problems of information asymmetry in the absence of collateral. Both types of lenders solved these problems by creating a new kind of collateral out of a mechanism that was meant to solve information asymmetries. And both did it without aid of legal rules.

The final observation about this convergence is that the credit market rather than the law is operating as the carrier of norms about things as fundamental as human worth. As we have seen, collateralization strengthens some aspects of human worth that might not otherwise have been so socially or culturally salient. This should come as something of a surprise to proponents of the rule of law who have argued that it is a necessary teacher of the norms of market behavior. In my examples, by quantifying and publicizing their use of human worth, the lenders themselves imprinted norms of utilitarian behavior, credit as a basic right and a source of wealth, transparency, and predictability. While this conclusion certainly does not vindicate the "invisible hand" theory of the market, it does suggest that the convergence described here is the result of a series of events that were not executed in a concerted manner or coordinated by experts. The provocative version of this point is that the market is playing a governing role that rule-of-law theorists expect to be played by governmental, legal and other experts.

Thus, the emergence of human worth as collateral ought to serve as a useful lesson both to proponents of globalized markets and to resistors. Both might better devote their attention to understanding convergences such as this one rather than advocating or resisting the exportation of formal laws. These examples suggest that globalization deeply affects the behavior of both lenders and borrowers. If these examples typify commercial practices more generally, then students of globalized markets would be well advised to study the mechanisms by which market actors in different local contexts solve problems of information asymmetry and other market failures. Indeed, if these examples signal a trend, then perhaps development experts in the East ought to seek out Western business people rather than Western lawyers. 